NBER WORKING PAPER SERIES

\title{
THE SHIFTING DRIVERS OF GLOBAL LIQUIDITY
}

\author{
Stefan Avdjiev \\ Leonardo Gambacorta \\ Linda S. Goldberg \\ Stefano Schiaffi \\ Working Paper 23565 \\ http://www.nber.org/papers/w23565
NATIONAL BUREAU OF ECONOMIC RESEARCH
1050 Massachusetts Avenue
Cambridge, MA 02138
June 2017

\begin{abstract}
Also published as BIS working paper no. 644. The authors thank anonymous referees and Matthieu Bussiere, Stijn Claessens, Catherine Koch, Robert McCauley, Patrick McGuire, Sergio Schmukler, Hyun Song Shin, Cedric Tille, Philip Wooldridge, and participants at the 3rd BISCGFS workshop on "Research on global financial stability: the use of BIS international banking and financial statistics" (Basel, May 2016), the ECB-FRB-FRBNY Global Research Forum on International Macroeconomics and Finance (New York, November 2016), Fordham University Macro International Finance Workshop 2017 (New York, April 2017), Chapman Conference on Money and Finance: Systemic Risk and the Organization of the Financial System (Los Angeles, May 2017), Central Bank of Turkey Annual Research Conference (Antalya, December 2017) and seminars at the Federal Reserve Bank of San Francisco and Bocconi University. Linda Goldberg developed parts of this project while visiting the Bank for International Settlements under the Central Bank Research Fellowship Programme. Stefano Schiaffi developed parts of this project during his $\mathrm{PhD}$ thesis and while visiting the Bank for International Settlements under the Research Fellowship Programme. Bat-el Berger and Pamela Pogliani provided excellent research assistance. The views expressed are those of the authors and do not necessarily reflect those of the Federal Reserve Bank of New York, the Federal Reserve System, the Bank for International Settlements, the Bank of Italy, or the National Bureau of Economic Research. All errors are our own.
\end{abstract}

NBER working papers are circulated for discussion and comment purposes. They have not been peer-reviewed or been subject to the review by the NBER Board of Directors that accompanies official NBER publications.

(C) 2017 by Stefan Avdjiev, Leonardo Gambacorta, Linda S. Goldberg, and Stefano Schiaffi. All rights reserved. Short sections of text, not to exceed two paragraphs, may be quoted without explicit permission provided that full credit, including $\odot$ notice, is given to the source. 
The Shifting Drivers of Global Liquidity

Stefan Avdjiev, Leonardo Gambacorta, Linda S. Goldberg, and Stefano Schiaffi

NBER Working Paper No. 23565

June 2017

JEL No. F34,G10,G21

\section{ABSTRACT}

The sensitivity of the main global liquidity components, international loan and bond flows, to global factors varied considerably over the past decade. The estimated sensitivity to US monetary policy rose substantially in the immediate aftermath of the Global Financial Crisis, peaked around the time of the 2013 Fed "taper tantrum", and then reverted towards pre-crisis levels. Conversely, the responsiveness of international bank lending to global risk conditions declined steadily throughout the post-crisis period. We show that the main driver of the fluctuations in the estimated sensitivities to US monetary policy was the degree of convergence among advanced economy monetary policies. Meanwhile, the post-crisis fall in the sensitivity of international bank lending to global risk was mainly driven by increases in the lending shares of better-capitalized banking systems.

\author{
Stefan Avdjiev \\ Bank for International Settlements \\ Centralbahnplatz 2 \\ Basel 4002, Switzerland \\ stefan.avdjiev@bis.org \\ Leonardo Gambacorta \\ Bank for International Settlements \\ Centralbanplatz, 24002 Basel \\ Switzerland \\ leonardo.gambacorta@bis.org
}

\author{
Linda S. Goldberg \\ Federal Reserve Bank-New York \\ 33 Liberty Street \\ New York, NY 10045 \\ and NBER \\ linda.goldberg@ny.frb.org \\ Stefano Schiaffi \\ Via Roberto Sarfatti, 25, \\ 20100 Milan, Italy \\ stefano.schiaffi@phd.unibocconi.it
}




\section{Introduction}

International capital flows channel financial resources across borders to both public and private sector borrowers. As such, they are critically important for economic growth and financial stability. Understanding their main drivers is crucial, as flows should contribute to economic growth and risk sharing internationally, without excessive volatility. Moreover, the structure and volatility of international loan and bond flows changed considerably in the aftermath of the Global Financial Crisis (GFC).

The initial sharp decline in cross-border loans after the GFC was followed by a feeble recovery and a second sharp contraction during the peak of the euro area crisis (Graph 1). Meanwhile, international bond issuance remained relatively robust. As a consequence, the composition of global liquidity has shifted away from cross-border bank loans and towards international bonds in what has been dubbed "the second wave of global liquidity" (Shin, 2013). Events such as the "taper tantrum" in 2013, when the Federal Reserve signalled it would start tapering its bond buying program, were marked by especially sharp capital outflows from a number of emerging markets (Khatiwada, 2017). An extensive literature has established that the two main global liquidity components, cross-border loan and bond flows through market-based participants, are impacted not only by local factors, but also by global factors. Advanced economy monetary policies and global risk aversion are established as the two most important global drivers (e.g. Forbes and Warnock, 2012a; Schularick and Taylor, 2012; Miranda-Agrippino and Rey, 2015; Cerutti, Claessens and Ratnovski, 2017; Ha et al., 2017). Yet, little attention has been paid to the time variation in the sensitivities of key capital flows to those drivers.

In this paper, we fill a key gap in the literature by studying the nature and the causes of the time variation in the sensitivities of the main components of global liquidity to global factors. Our contribution to this important strand of the literature has multiple layers. First we document in a robust manner that the sensitivity of the main global liquidity components to global factors varied considerably in the period after the GFC. Second, we decompose the variation in sensitivities into behavioural components and compositional components of banking systems participating in global liquidity flows. Last but not least, we drill down into 
the observed time variation, examine its proximate reasons, and distinguish between persistent versus transitory drivers.

This empirical analysis takes advantage of the rich dimensionality of multiple datasets - the BIS International Debt Securities (IDS) Statistics, the BIS Locational Banking Statistics (LBS) and the BIS Consolidated Banking Statistics (CBS). The combined information in the above datasets facilitates examining the behaviour of key global liquidity components while distinguishing among borrowing countries, lending national banking systems, instrument types (debt securities versus bank loans), borrowing sectors (bank versus non-bank). We also utilise information on lending banking systems' balance sheet characteristics and on monetary and prudential policy developments in both borrowers and creditor countries. The combination of the above datasets generates a rich quarterly panel of international bank loan and bond flows to 64 recipient countries for the period between 2000:Q1 and 2015:Q4.

The first key set of results documents the considerable shift in international capital flow sensitivities to global drivers since the GFC. US monetary policy became a more potent driver of both cross-border loan and international bond flows, with estimated policy impact peaking in 2013 and then partially retracing toward pre-crisis levels. Our estimates suggest that a 100-basis point increase in the Federal funds rate would reduce total cross-border flows by an estimated 8 percent in the years immediately after the crisis and by 4.5 percent afterwards, up from just 2 percent pre-crisis. Meanwhile, the sensitivity of cross-border bank loan flows to global risk conditions declined considerably post-crisis and became similar to the traditionally lower risk sensitivity of international bond flows. A one-percent change in the VIX measure would reduce total cross border flows by 3 percent pre-crisis, with this effect falling to about 1 percent after 2013. Overall, aggregate global liquidity flows (the sum of international bank loan and bond flows) became more sensitive to US monetary policy and less sensitive to global risk after the GFC.

The second key set of results reveals that the dynamics of the sensitivities to the two major global drivers (US monetary policy and global risk conditions) are explained by fundamentally different sets of factors. The post-crisis fluctuations in the sensitivities to US monetary policy were driven by transitory behavioural factors. By contrast, the post-crisis 
fluctuations in the sensitivities to global risk conditions were primarily driven by persistent creditor compositional factors.

The third set of key results pinpoints the main determinants of the post-crisis shifts in sensitivities. The increased post-GFC sensitivity to US monetary policy is shown to be attributed to a higher degree of monetary policy convergence among advanced economies in the years following the GFC, with US monetary policy serving as a stronger indicator of global monetary policy trends. This effect began to unwind as the monetary policies of major advanced economies started to diverge in 2013. Meanwhile, the decline in the sensitivity to global risk occurred mainly as a result of a post-crisis shift in the composition of global lenders: the better-capitalized national banking systems, which tend to be less responsive to global risk conditions, significantly increased their market share.

These results have important implications for global liquidity flows. First, the finding that the post-GFC increases in sensitivities to US monetary policy were driven largely by the unusual convergence in advanced economy monetary policies suggests that they were largely a transitory phenomenon. This result also implies that greater cross-country business cycle (and, consequently, monetary policy) synchronization would make the stabilisation of international capital flows more challenging. Second, the finding that the overall decline in the sensitivity of international bank flows to global risk conditions was due to increases in the lending market shares of better-capitalized banking systems, which are themselves less responsive to global risk, suggests that the post-GFC regulatory reforms had the additional benefit of stabilising international capital flows.

The remainder of the paper is organised as follows. In Section 2, we review relevant findings of the existing literature on global liquidity and its drivers. We describe the data in Section 3. We estimate the sensitivities to global factors and their post-crisis shifts in Section 4. In Section 5, we decompose these shifts into behavioural components and compositional components. In Section 6, we examine the drivers of the post-crisis shifts in sensitivities. We present robustness tests in Section 7 and conclude in Section 8. 


\section{Previous literature}

Global liquidity and drivers have been explored in many related studies. The most extensive literature is on international capital flows. A second strand of literature is more explicitly focused on global liquidity, international debt securities versus loans, and balance sheet constraints across banks and non-banks. A third strand addresses international monetary policy spillovers, covering the transmission channels through banks and capital markets, interest rate and asset price co-movements, and the broader structure of the international monetary system and policy instrument availability.

The large literature on the drivers of capital flows historically focuses most extensively on emerging market economies (EMEs), and more recently considers advanced economies also as destinations of capital. Surges in cross-border flows to EMEs reflect improved macroeconomic fundamentals of the borrowing country (pull and local factors) and more favourable global conditions of a primarily cyclical nature (push and global factors). ${ }^{2}$ Studies of gross (as opposed to net) international flows and distinguishing across different institutional participants provide a window in the mechanisms which shocks transmit internationally. Higher volatility is observed in gross flows than in net flows, specifically in the context of business cycles and crises (Broner et. al., 2013). The most extreme capital flows episodes are driven by global factors, notably global risk aversion, particularly visible when extreme episodes are classified into four categories: surges, stops, flight and retrenchment (Forbes and Warnock, 2012b). Within the various capital flows components, the Global Financial Crisis demonstrated the dominant contraction of international banking flows and the relative stability of foreign direct investment (Milesi-Ferretti and Tille, 2011). Regional reallocations in international participation also occurred, with post-crisis declines in bankbased cross-border lending, particularly by euro area banks, alternatively described as financial deglobalization (Rose and Wieladek, 2014; Forbes et al., 2015) or "the great crossborder bank deleveraging" (Cerutti and Claessens, 2017; Bussière et al., 2018) or mainly just a cyclical deleveraging of European banks' large overseas operations (Benetrix, McCauley, McGuire, von Peter, 2019). Possible explanations include weaker economic activity, capital

\footnotetext{
2 Examples of such studies include those by Calvo et al. (1993), Ghosh and Ostry (1993), Fernandez-Arias (1996), Taylor and Sarno (1997), and Chuhan et. al. (1998). See Koepke (2015) for a comprehensive summary of the literature in the drivers of capital flows to emerging markets.
} 
controls, the slower pace of financial liberalization, deleveraging, and risk aversion (CGFS 2011).

Micro-banking data analyses show which bank-specific features magnified contractions or expansions post-crisis. Individual global banks received balance sheet shocks through holdings of asset-backed commercial paper (Cetorelli and Goldberg, 2012a), or later through exposure to European sovereign debt (Popov and van Horen, 2015). Transmission of impulses through global banks to their affiliate locations internationally via internal capital markets follows a pecking order, with the degree of shock transmission to countries dependent on their bank-specific importance in lending and funding activity (Cetorelli and Goldberg, 2012b). Prudential policies and unconventional monetary policy in the form of a funding for lending scheme jointly contributed to a retrenchment of cross-border lending by UK banks (Forbes, Reinhardt and Wieladek, 2017). Consistent with these observations, some countries with banks that were well-capitalized pre-crisis, like Canada, expanded international activities post-crisis when foreign jurisdictions tightened capital requirements (Damar and Mordel, 2017). Overviews of results from macroprudential policy spillover studies and monetary policy spillovers likewise tend to find roles for bank capitalization and business models (Buch and Goldberg, 2017; Buch, Bussiere, Goldberg and Hills, 2019).

Meanwhile, bank balance sheet characteristics clearly matter for responses to shocks. Higher bank capital, and more retention of bank earnings, reduces the cost of debt financing, increases bank lending growth, and reduces the magnitude of monetary policy transmission into lending (Gambacorta and Shin 2018). US monetary policy tightening and episodes of dollar appreciation are associated with deleveraging of global banks, reduced capital flows to emerging markets, and an overall tightening of global financial conditions (Bruno and Shin, 2015). Banks have more pronounced bank lending channel responses to liquidity risk when they have low levels of capitalization and low deposit funding shares (Cornett et al. 2011; Buch and Goldberg, 2015). Evidence from a large cross-country initiative on monetary policy consequences for lending flows to nonbanks through global banks shows a mixture of bank characteristics matter, even while the effects are not always quantitatively large (Buch, Bussiere, Goldberg, and Hills, 2019). 
Beyond banks, a post-crisis shift in international financial intermediation has occurred, with a reduction in the role of bank lending and an increase in bond market financing internationally. The bank-dominated phase of global liquidity was partially replaced by a second bond-dominated phase of global liquidity (Shin, 2013). ${ }^{3}$ This composition links the evolution of global monetary aggregates to the financial activities of non-financial corporations (NFCs), with the non-core liabilities of NFCs reflecting global credit conditions and predicting global trade and growth (Chung et. al., 2016). Of course, these shifts also result from policy developments. Unconventional monetary policy contributed to shifting the balance of dollar credit transmission from global banks to global bond investors, as demonstrated by a post-crisis negative relationship between the term premium on 10-year Treasury bonds and international bond issuance (McCauley et. al., 2015). Regulatory changes also have played a role in this transition as banks were subjected to tighter requirements. Monetary policy rates across a large sample of countries can closely track advanced economy policy rates, particularly those of countries playing a central role in the international monetary system (Obstfeld, Shambaugh and Taylor, 2015). The form of exchange rate and monetary regimes in place influences the degree of co-movement. Greater near term autonomy has been linked to some restrictions on international capital movements (Klein and Shambaugh, 2008) and lower levels of banking globalization (Goldberg 2013).

We contribute to this broader literature by examining the flows through both banks and non-banks as borrowers and lenders. Our analysis of the effects of key global liquidity drivers, including risk and advanced economy monetary policy, demonstrates structural breaks, and tests conjectures about why and how effects of key drivers change over time. Our analysis documents the clear influence of advanced economy monetary policy stances, lenders' balance sheet characteristics and creditor composition on the shifting drivers of global liquidity.

\footnotetext{
${ }^{3}$ These observations pertain to volumes of cross-border flows, not to co-movements of asset prices. During this same broad period, co-movements in international asset prices continue to be at least as strong and sensitive to global risk sentiment and liquidity conditions as pre-crisis state. This type of evidence does not support de-globalization.
} 


\section{Data}

We use three databases to capture the dimensionality needed to explore the main components of global liquidity: the BIS Locational Banking Statistics (LBS), the BIS International Debt Securities Statistics (IDSS), and BIS Consolidated Banking Statistics (CBS). The BIS LBS captures the outstanding claims and liabilities of internationally active banks located in 44 BIS LBS reporting countries ${ }^{4}$ against counterparties residing in more than 200 countries. Banks record their positions on an unconsolidated basis, including intragroup positions to capture international flows between offices of the same banking group. The data, which are aggregated at the country level and compiled following balance of payments statistics principles, capture around 95\% of all cross-border interbank business (Bank for International Settlements, 2015). The counterparty sector breakdown available in the BIS LBS enables us also to distinguish between cross-border bank lending to bank and non-bank borrowers. We use the BIS CBS in order to obtain information on the relative importance of lending countries for a given borrowing country. The BIS IDSS data capture borrowing in money and bond markets. They encompass what market participants have traditionally referred to as foreign bonds and eurobonds. International debt securities (IDS) are issued in a market other than the local market of the country where the borrower resides (Gruic and Wooldridge, 2012). The sample used for the empirical analysis consists of quarterly data from Q1 2000 to Q4 2015. On the borrowing side, we focus on a set of 64 countries; on the bank lending side, we use data on the positions of all 44 BIS LBS and 31 CBS reporting countries. ${ }^{5}$

The typical lenders and borrowers connected by each flow type differ considerably in composition and size, as illustrated within Table 1. Cross-border loans are typically supplied by internationally-active banks, which tend to be relatively large. Meanwhile, the creditors in international debt securities markets are usually non-bank financial intermediaries, such as pension funds, insurance companies, money market mutual funds, and hedge funds. The variation on the borrower side is even greater. International bond issuance by non-banks tends to be dominated by sovereigns and large non-financial corporates. The latter are also

\footnotetext{
${ }^{4}$ The complete list of BIS LBS reporting countries is provided at http://www.bis.org/statistics/rep countries.htm.

${ }^{5}$ The complete lists of all borrowing countries and lending national banking systems are available in Annex A.
} 
important players on the borrowing side of the cross-border bank loan market, which also channels funds to export/import firms and leveraged non-bank financials.

Appropriately capturing changes in stance of US monetary policy is key for our analysis. The existing empirical literature discussed in Section 2 mainly corresponds to the period prior to the introduction of unconventional monetary policy and almost exclusively uses a short-term policy rate. However, monetary policy at the zero lower bound is a defining feature of the post-crisis period, and changes in communications, interest on effect reserves and quantitative easing actions became more instrumental. We use the Wu-Xia policy measure (Wu and Xia, 2016) as a sufficient statistic for the stance of US monetary policy. This construct uses the effective US Federal Funds target rate prior to Q4 2008 and estimates of the shadow Federal Funds rate from Q1 2009 through end of 2015 (Graph 2, left panel). Since all shadow rate estimates are sensitive to the underlying modelling assumptions, we also conduct robustness analysis using alternative US monetary policy measures (Section 7).

We proxy for monetary policy divergence among advanced economies using the difference between the two-year futures on the policy rate for the United States and the average of the two-year futures on the respective policy rates for the United Kingdom, Switzerland, Japan and a group of "core" Eurozone countries (Austria, Belgium, Germany, Finland, France, the Netherlands, Spain). ${ }^{6}$ As shown in Graph 3, monetary policy divergence was unusually small in the years immediately following the Global Financial Crisis, with the gap opening up again after 2013.

For global risk conditions we follow the literature in our baseline by using the VIX index of the implied volatility in S\&P500 stock index option prices from Chicago Board Options Exchange (CBOE). As alternative metrics have been derived in the finance literature to separate out risk sentiment from underlying risk levels, we perform robustness results using the Bekaert, Engstrom and Xu (2017) risk index. Very similar results arise as the two measures are strongly positively correlated (Graph 2, right panel).

Three borrowing country variables (pull factors) are included in baseline specifications: local real GDP growth, sovereign ratings, and the degree of financial

\footnotetext{
${ }^{6}$ Summary statistics for the explanatory variables used in our empirical analysis are presented in Table B1 in Annex B.
} 
openness. For each borrowing country, the sovereign ratings variable is defined as the average ratings across the three major credit ratings agencies (S\&P, Moody's and Fitch). The degree of financial openness is captured by the Chinn-Ito index (Chinn and Ito, 2008), normalized between 0 and 1 . In addition, we account for changes in prudential policy. The IBRN Prudential Instruments dataset covers widely-used prudential instruments, keeping track of the intensity of their usage in 64 countries between 2000 and 2014 at a quarterly frequency. The instruments that are covered are: general capital requirements, sector-specific capital requirements (split into real estate credit, consumer credit, and other), interbank exposure limits, concentration limits, loan-to-value (LTV) ratio limits, and (local currency and foreign currency) reserve requirements. We specifically focus on the three prudential policy instruments that have been shown to have the largest impact on international bank lending: loan-to-value ratio caps, capital requirements and local currency reserve requirements (Cerutti et al., 2017; Avdjiev et al., 2017; and Buch and Goldberg, 2017). ${ }^{7}$

The balance sheet characteristics of national banking systems are constructed using Bankscope data. We obtain the balance sheet items of interest for the set of internationally active banks that report to the BIS consolidated banking statistics, and then aggregate banklevel characteristics to national banking system-wide variables, using weighted averages across the individual banks of a given nationality. Data are adjusted for mergers and acquisitions to correct for balance sheet jumps that are unrelated to lending (Brei et al., 2013). We focus on i) capital to total assets, ii) average bank size, iii) deposits to total assets, iv) net interest income over total income, and v) net interest income to total assets. Two bank business model measures considered are: i) an income diversification ratio (defined as net interest income to total income); and ii) net interest income to total assets. The first indicator ranges from 0 to 1 and indicates the fraction of a bank's profitability that derives from traditional intermediation activity (i.e. lending and deposits). If a bank has a large portion of non-interest income (trading income, fees and commissions for services) than this indicator tends lower values. The second indicator is the return per unit of assets that derives from traditional intermediation activity. It represents the profitability of intermediated assets that is obtained by the bank getting deposits and supplying loans.

\footnotetext{
${ }^{7}$ Cerutti et al. (2017) provide an extensive discussion of the properties of the quarterly changes in these prudential instruments and the cumulative changes over time.
} 


\section{Post-crisis shifts in sensitivities to global factors}

We start our empirical analysis by estimating a specification that is commonly used in the existing literature. ${ }^{8}$ In it, the main global liquidity components are functions of global (push) and country-specific (pull) drivers. We replicate findings from that literature as a baseline before delving into differences in sensitivities across different borrower groups (banks and non-banks) and across different types of financing instrument (international loan and bond flows).

The baseline model for international capital flows is given by:

$$
\begin{aligned}
& \operatorname{GrRateY}_{t}^{j}=\beta_{1} \Delta F F R_{t}+\beta_{2} \log V I X_{t}+\beta_{3} \Delta \log G \text { lobalGDP } P_{t} \\
& +\beta_{4} \Delta \text { SovRating }{ }_{t}^{j}+\beta_{5} \text { ChinnIto }_{t}^{j}+\beta_{6} \Delta \log G D P_{t}^{j}+\mu^{j}+\varepsilon_{t}^{j}
\end{aligned}
$$

where $j$ denotes borrowing country and $t$ is time. This baseline specification considers the issue of international capital flows and global liquidity drivers from the perspective of the borrowing country. Global liquidity is divided into component cross-border flows by instrument and by type of borrower, with these components explored separately and in aggregate. For our analysis, $Y_{t}^{j}$ can be cross-border loans - to all sectors, to banks, to nonbanks - or international debt securities - issued by all sectors, by banks, or by non-banks. As is standard in the literature, the model is expressed in stationary variables to avoid problems of spurious correlations. The international flows on the left-hand side of the equation are expressed in growth rates $\operatorname{GrRate} Y_{t}^{j}$. All specifications include country fixed effects $\mu^{j}$.

The right-hand-side of the equation contains three global liquidity drivers - the US federal funds rate $F F R_{t}$ (as a gauge for the stance of US monetary policy), the VIX (as a measure global risk conditions) and global GDP (as an indicator of global economic activity). As the US federal funds rate does not reflect all of the monetary policy interventions for the post GFC period, we use the Wu-Xia shadow rate measure (Wu and Xia, 2016) as a proxy to

\footnotetext{
${ }^{8}$ As discussed in Cerutti, Claessens and Rose (2017), this type of specification dates back to Calvo et al (1993, 1996) and has a long history of applications. Koepke (2015) provides a review of approximately 40 papers, with recent panel regressions in Fratzscher (2011), Forbes an Warnock (2012), Broner et al (2013), Bruno and Shin (2015), and Cerutti, Claessens and Ratnovski (2017). Goldberg and Krogstrup (2018) derive similar specifications from a model of capital flow pressures using balance of payments and international portfolio demand equilibrium conditions.
} 
reflect both conventional and unconventional monetary policies. ${ }^{9}$ The local factors corresponding to borrowing country $j$ and flow type include sovereign credit ratings SovRating $t_{t^{\prime}}^{j}$ the Chinn-Ito index of financial openness ChinnIto ${ }_{t}^{j}$ (Chinn and Ito, 2008) and local GDP growth $\log G D P_{t}^{j}$. The latter measures overall economic performance. Sovereign ratings proxy the role of country risk and the perceived creditworthiness of borrowers by country. The Chinn-Ito index gauges the degree of capital account openness. The Fed funds rate and the sovereign ratings are in first differences, while local and global GDP are in growth rates. The Chinn-Ito index is in levels and the VIX enters the equation in logs. ${ }^{10}$ The model is estimated under the assumption that the two key global liquidity drivers, the Fed funds rate and the VIX, are exogenous when controlling for local and global GDP, government ratings and degree of financial openness ${ }^{11}$.

The estimated coefficients from the baseline specification in equation (1) for the entire sample 2000:Q1 - 2015:Q4, presented in Table 2, are largely in line with those obtained in the existing literature. Namely, the results from the baseline model indicate that an increase in global risk conditions (measured by the VIX) has a negative and strongly statistically significant effect on all (loan and bond) flows. The US federal funds rate has a sharply negative impact on cross-border bank loans. Its estimated impact on international debt securities is also negative, albeit only marginally statistically significant. Local factors are statistically significant drivers. Borrowing countries with higher GDP growth rates and with better sovereign credit ratings tend to attract more cross-border loans. The degree of financial openness, as reflected in the Chinn-Ito index, has a positive (and statistically significant) effect on the international bond flows, especially to banks.

As both anecdotal evidence and the literature discussion of phases of financial globalization hint at the presence of a possible structural break around the global financial crisis, we relax the (implicit) constant-coefficient assumption of the existing literature and

\footnotetext{
${ }^{9}$ As there are multiple shadow policy rates available in the literature, we perform extensive robustness checks using alternative indicators of U.S. monetary policy. The main findings are robust to alternative proxies.

${ }^{10}$ The Chinn-Ito index is only available at an annual frequency. We have tested the robustness of the results by using a quarterly linear interpolation of the Chinn-Ito index and by eliminating the index from the regressions. In both cases, the main results of the study remain qualitatively similar.

${ }^{11}$ We add the following controls in robustness checks: lagged flows, the borrowing country's monetary policy stance (proxied by the borrowing country's policy rate), the log change of the exchange rate between the borrowing country's currency and the US dollar, the change in longer maturity interest rates. See Section 6.2 for details.
} 
allow for time variation in the impacts of the key global liquidity drivers. More concretely, we formally examine whether the estimated coefficients from equation (1) are stable over time. Rather than exogenously imposing an ad-hoc break date, we test for its presence and exact timing endogenously. Using the tools developed in Bai (1994, 1997), Kurozumi (2002) and Carrion-i-Silvestre and Sansó (2006), for each quarter T starting in 2007:Q1, we estimate the following equation:

$$
\operatorname{GrRate}_{t}^{j}=\beta^{\prime} X_{t}^{j}+\mu^{j}+I(t \geq T)\left(\kappa+\gamma^{\prime} X_{t}^{j}\right)+\varepsilon_{t}^{j}
$$

where

$$
X_{t}^{j}=\left(\Delta F F R_{t}, \log V I X_{t}, \Delta \log G \operatorname{lobalGDP} P_{t}, \Delta \log G D P_{t}^{j}, \Delta \text { SovRating }_{t}^{j}, \text { ChinnIto }_{t}^{j}\right)^{\prime}
$$

and $I(t \geq T)$ is an indicator function that takes the value 1 when $t \geq T$ and 0 otherwise. Notice that for each candidate break date $T$, all the parameters of equation (2) are different. For each type of cross-border flow $Y$ and each quarter $T$ we compute the sum of squared residuals $(S S R)$ of the regression in order to get a sequence $\left\{S S R_{T}^{Y}\right\}_{T \geq 2007: Q 1}$. The most likely candidate for the break is the date $T$ that minimizes the sequence, hence maximizing the fit of the model: $T_{\text {break }}^{Y}=\operatorname{argmin}_{T \geq 2007: Q 1}\left\{S_{S} R_{T}^{Y}\right\}$. Once we detect the endogenous date for the break $\left(T_{\text {break }}^{Y}\right)$, we re-estimate the baseline model with the appropriate break dummy and use a Wald test on $\kappa$ and $\gamma^{\prime}$ to determine whether the break is statistically significant. The vector $\beta^{\prime}$ captures the sensitivities of international financial flows to the drivers in $X_{t}^{j}$ before the break. The sum $\beta^{\prime}+\gamma^{\prime}$ captures the post-break sensitivities.

The results we obtain from the above formal tests suggest that the break date for both main global liquidity components (cross-border loan flows and international bond flows) is 2009:Q1. Wald (or Chow) tests on the coefficients $\kappa$ and $\gamma^{\prime}$ in equation (2) indicate that the break is statistically significant for the global liquidity components that we examine. $^{12}$

Table 3 summarizes the estimated sensitivities to the main global drivers (the federal funds rate and the VIX) during the pre-crisis and the post-crisis periods, respectively. Two sets of estimates are provided for the post-crisis period - one for the full sample (ending in Q4:2015) and one for a sub-sample ending in Q1:2013. The latter set of results provides

\footnotetext{
12 Test results are available upon request.
} 
initial perspective on how the 2013 Fed taper tantrum, which started the divergence across advanced economy monetary policies, marked a turning point in the post-crisis sensitivities to global factors ${ }^{13}$.

The results confirm that the relationship between the main global factors and international capital flows (from the borrowing country perspective) has changed profoundly since the Global Financial Crisis ${ }^{14}$. The impact of US monetary policy on cross-border loans, which was already negative and statistically significant during the pre-crisis period, rose even further in the immediate aftermath of the GFC. While prior to the crisis a 100-basis point increase in the federal funds rate was associated with a 3 percent decline in cross-border bank lending flows, in the aftermath of the crisis this effect rose to 8 percent. The respective negative impact on international bond issuance, which was not statistically significant prior to the crisis, also increased considerably after the GFC. In quantitative terms, the impact of a 100-basis point increase in the federal funds rate on international bond issuance surged from slightly more than 1 percent before the crisis to 8 percent immediately after the crisis.

After 2013, global liquidity sensitivities to US monetary policy reverted towards their respective pre-crisis levels, especially for cross-border loans. Once the sample is extended to include the post-taper tantrum period, a 100-basis point increase in the federal funds rate becomes associated with an approximate 3 percent decrease in loan flows, a level of responsiveness much closer to the one observed prior to the crisis. The responsiveness of international bond flows reverted to about 4 percent.

The sensitivity of both loans and bonds to global risk conditions declined sharply. Whereas prior to the crisis a 1 percent change in the actual VIX measure was associated with an approximate 4 percent contraction in loan flows, after the crisis this effect became statistically insignificant and about 32 basis points in magnitude. Similarly, the sensitivity of bonds to a 1 percent increase in the VIX declined from a peak of about 3 percent right after

\footnotetext{
${ }^{13}$ As a robustness exercise, we replicate the analysis using a smaller pre-crisis sample (2002:Q1 - 2008:Q4) to match the span of the post-crisis one (2009:Q1 - 2015:Q4). The signs, magnitudes and time patterns of the coefficients are very similar and qualitatively the same as those in Table 3. All results from that robustness exercise are available upon request.

${ }^{14}$ Table B2 in Annex B presents the results from formal tests of the significance in the differences between the estimated coefficients of US monetary policy and global risk (reported in Table 3) for key sample periods (post-break - up to 2015:Q4 or up to 2013:Q1 - minus pre-break, as well as post-break up to 2015:Q4 minus post-break up to 2013:Q1). Each difference in estimated coefficients is accompanied by its robust standard error; the stars represent the usual conventional significance levels, computed using a t-test on the difference between the two coefficients.
} 
the crisis to slightly more than 1 percent afterwards. These findings are in line with the argument of Shin (2016) that the VIX has lost its power as a barometer of banks' appetite for leverage since the GFC.

Given our special interest in the sensitivities of international loan and bond flows to US monetary policy and global risk conditions, we conduct an additional closer investigation of the evolution of the respective estimated coefficients. In particular, we sequentially estimate equation (2) with the appropriate break date, starting with data for 2000:Q1 - 2013:Q1 and adding one quarter at time until we reach the full sample period (2000:Q1 - 2015:Q4).

The above procedure generates a distinct set of parameter estimates for each sampleend quarter from 2013:Q1 through 2015:Q4. This allows us to track how sensitivities to US monetary policy and global risk conditions have evolved during that period. As with the baseline analysis, for this approach to time variation $Y_{t}^{j}$ respectively covers gross flows of cross-border loans to all sectors, to banks, to non-banks, and international debt securities issued by all sectors, by banks or by non-banks, all taken from borrower country j's perspective ${ }^{15}$.

This deeper empirical analysis reveals considerable variation in the estimated parameters of interest across global factors through the post-crisis period, as shown in Graphs 4 and 5. The graphs also include in each panel a black line designating the pre-crisis estimates of comparable sensitivities. The post-crisis evolution of the sensitivity to US monetary policy is dramatic, and common across instruments and borrowing sectors (Graph 4). It is strongest right before the start of the US taper tantrum and becomes gradually weaker afterwards. By the end of 2015, sensitivities remain stronger than during the pre-crisis period for all but one of the global liquidity components.

The sensitivity to global risk conditions decreases steadily throughout the post-GFC period (Graph 5). Notably, even though the estimated sensitivities are still significantly lower than zero in mid-2013, this is not the case by 2015. In the case of cross-border loans, the sensitivity to global risk conditions is significantly weaker in the post-crisis period than in pre-crisis. The sensitivity of international debt securities to the VIX is almost always not

\footnotetext{
${ }^{15}$ The approach described above may be subject to shrinking confidence bands over time due to artificially larger samples. As a robustness exercise, we compute rolling window estimates with a fixed sample size of 16 quarters. The results generated by this alternative estimation, which are available upon request, are very similar to the benchmark estimates.
} 
significantly different from zero, with the only exception being flows of bonds issued by nonbanks ${ }^{16}$.

\section{Decomposing the shifts in sensitivities to global factors}

The next step of the empirical investigation examines the deeper underlying causes of the shifts in sensitivities to global factors documented in the previous section. More concretely, the shifts in the sensitivities are decomposed into compositional components and behavioural components.

Since the baseline specifications include controls for local country $j$ drivers of global liquidity, the evolution of estimated global factor coefficients $\beta_{1}$ and $\beta_{2}$ on advanced economy monetary policy and risk are associated with creditors. For any class of creditor and borrower type, the aggregate sensitivities of international bank lending flows to global factors $\left(\beta_{1}\right.$ and $\left.\beta_{2}\right)$ can be expressed as weighted averages of the national creditor-specific sensitivities to global factors $\left(\beta_{1}^{i}\right.$ and $\beta_{2}^{i}$ ). Some changes in estimated $\beta_{1}$ and $\beta_{2}$ are attributable to a combination of shifts in the composition of international creditors (a compositional component) and shifts in the sensitivity of flows from each respective country creditor vis-à-vis advanced economy monetary policy and risk metrics (a behavioural component). While this observation is general, our derivation of the decomposition takes the perspective of international bank lending.

Re-writing $\operatorname{GrRate} Y_{t}^{j}=\frac{s_{t}^{j}}{s_{t-1}^{j}}-1$, where $S_{t}^{j}$ is the outstanding stock of all international bank lending to the residents of borrowing country $j$ at the end of period $t$, expanding and simplifying yields:

$$
\frac{S_{t}^{j}}{S_{t-1}^{j}}-1=\frac{\sum_{i} S_{t}^{i, j}}{\sum_{i} S_{t-1}^{i . j}}-1=\sum_{i}\left(\frac{S_{t}^{i, j}}{S_{t-1}^{i, j}} * \frac{S_{t-1}^{i, j}}{\sum_{i} S_{t-1}^{i, j}}\right)-1=\sum_{i}\left\{\left(\frac{S_{t}^{i, j}}{S_{t-1}^{i, j}}-1\right) w_{t-1}^{i, j}\right\}
$$

where the weight for each creditor banking system $i, w_{t-1}^{i, j}=\frac{s_{t-1}^{i, j}}{\sum_{i} s_{t-1}^{i, j}}$ equals the respective share of the outstanding stock for which it accounts. The national banking system-specific counterpart to specification (1) is then written as:

\footnotetext{
${ }^{16}$ These results are qualitatively the same when we study the time-variation of the parameters using a rolling window of 16 quarters.
} 


$$
\begin{gathered}
\frac{S_{t}^{i, j}}{S_{t-1}^{i, j}}-1=\beta_{1}^{i} \Delta F F R_{t}+\beta_{2}^{i} \log V I X_{t}+\beta_{3}^{i} \Delta \log \text { GlobalGDP} P_{t}+\beta_{4}^{i} \Delta \text { SovRating }_{t}^{j} \\
+\beta_{5}^{i} \text { ChinnIto }_{t}^{j}+\beta_{6}^{i} \Delta \log G D P_{t}^{j}+\mu^{i, j}+\varepsilon_{t}^{i, j}
\end{gathered}
$$

Combining (4) and (5), the baseline regression specification implies that the observed borrower $j$ sensitivities to the federal funds rate $\left(\beta_{1}\right)$ and to the $\operatorname{VIX}\left(\beta_{2}\right)$ can be expressed as weighted averages of the respective sensitivities $\left(\beta_{1}^{i}\right)$ and $\left(\beta_{2}^{i}\right)$ for the individual lending national banking systems: ${ }^{17}$

$$
\beta_{1}=\sum_{i}\left\{w_{1, t-1}^{i, j} \beta_{1}^{i}\right\} \text { and } \beta_{2}=\sum_{i}\left\{w_{2, t-1}^{i, j} \beta_{2}^{i}\right\}
$$

The compositional component is captured by the $w_{1}^{i \prime} s$ and $w_{2}^{i \prime} s$ and the behavioral component is captured by the $\beta_{1}^{i \prime} s$ and $\beta_{2}^{i \prime} s$. The compositional factors $w_{1}^{i \prime} s$ and $w_{2}^{i \prime} s$ are directly observable from data on bilateral international claims. Meanwhile, we estimate the behavioural factors $\beta_{1}^{i \prime} s$ and $\beta_{2}^{i \prime}$ s using a variant of the baseline specification.

The above decomposition procedure is implemented by taking advantage of the BIS consolidated banking statistics (CBS). The BIS CBS contains bilateral data on banks' international claims ${ }^{18}$, with information on the nationality of the lending banks $(i)$ and on the residence of the borrower (j). The composition of lending national banking systems (the $w_{1}^{i \prime} s$ and the $w_{2}^{i \prime} s$ ) is directly observable and obtained from the CBS matrix of bilateral stocks of international claims. Meanwhile, the factors that capture the behavioural component, i.e. the national banking system-specific sensitivities to global factors (the $\beta_{1}^{i \prime} s$ and the $\beta_{2}^{i \prime} s$ ), are obtained as the estimated coefficients on the respective global factors in the creditorcountry banking system-specific regressions presented in equation (6). Thus, we provide the creditor country history of changes in sensitivities and the precision of estimates of those sensitivities for global liquidity flows through international banks to both bank and non-bank counterparties. $^{19}$

After obtaining the pre- and post-crisis lender-specific weights and lender-specific sensitivities to global drivers, we estimate the contributions of the behavioural components

\footnotetext{
${ }^{17}$ A detailed explanation of the decomposition of post-crisis shifts in sensitivities can be made available upon request.

${ }^{18}$ In the BIS CBS, international claims are defined as the sum of cross-border claims and local claims denominated in foreign currencies.

${ }^{19}$ As comparable data is not available for market-based finance, our decomposition does not extend to international debt securities.
} 
(the first terms on the right-hand side of equations (7) and (8)) and compositional components (the second terms on the right-hand side of equations (7) and (8)) to the shifts in sensitivities from the perspective of borrowers. ${ }^{20}$ Recall that a borrower can experience a changing sensitivity of financing flows to global factors if there is an evolution in the composition of creditors, where the creditors have distinct sensitivities, and if there is an evolution of the behavioural sensitivities of creditors.

The results from the decompositions of borrower sensitivities into the composition and behaviour of creditors are summarized in Graph 6. The behavioural component dominates the shifts in realized borrower sensitivities to US monetary policy (Graph 6, lefthand panel). For all three borrowing sectors, the estimated contributions of the behavioural component are negative (i.e. they increase the absolute value of the estimated sensitivity). The contributions of the behavioural component dwarf the respective contributions of the compositional component. These results strongly suggest that the post-crisis increases in the sensitivity of international bank lending flows to US monetary policy were driven by increases in the sensitivities of individual banking systems rather than by shifts in the composition of international lending from less to more sensitive banking systems.

The decomposition of the sensitivities to the VIX show that the contributions of the compositional component are all positive and much larger than their counterparts for the US monetary policy sensitivities (Graph 6, right-hand panel). The overall declines in sensitivities to the VIX of both lending to the non-bank private sector and interbank lending are clearly driven by the compositional component. The behavioural component is not nearly as dominant as in the case of US monetary policy and plays a non-negligible role only for lending to the public sector.

The sensitivities of international bank lending flows to the public sector increase considerably during the post-crisis period vis-à-vis both the US monetary policy and the VIX. These results could be interpreted as evidence that banks have adjusted treatment of sovereign risk since the crisis. Such an interpretation is consistent with evidence that banks treated (most of) their sovereign exposures as virtually risk-free before the crisis, but started

\footnotetext{
20 By design, these decompositions represent approximations of the underlying estimation procedure. Even though the "synthetic" sensitivities derived as a weighted average of the lender-specific sensitivities tend to be very close to the global sensitivities obtained using the benchmark regression specification, the two measures do not overlap perfectly.
} 
to assess sovereign risk in a more realistic manner after the crisis (Acharya et al., 2013; Farhi and Tirole, 2016; De Grauwe and Ji, 2013).

\section{Drivers of the post-crisis shifts in sensitivities}

Having decomposed the post-crisis shifts in the sensitivities into compositional components and behavioural components, we attempt to identify the key individual drivers of those components. We conjecture that the evolution of the estimated sensitivities to US monetary policy may be influenced by the overall advanced economy (AE) monetary policy stance. The reaction to US monetary policy as a global liquidity driver could be especially pronounced if it is a signal for a broader based set of (expansionary) policies across $\mathrm{AE}$ countries. In the period between the global financial crisis and the 2013 Fed taper tantrum, there was considerable convergence between the monetary policies of advanced economies, all of which were conducting various forms of quantitative easing to stimulate the real economy. In 2013, the Federal Reserve signalled that it would start tapering its bond buying program. As the central banks of other advanced economies, most notably the European Central Bank and the Bank of Japan, did not follow suit, the monetary policies of advanced economies diverged from 2013 through the end of our estimation period in 2015, with divergence metrics returning to levels that were common pre-crisis. Thus, we conjecture that the sensitivities to US monetary policy could be stronger during the convergence period and weaker as policy diverges. Indeed, the left-hand panel of Graph 7 already provides some preliminary evidence in support of that hypothesis by illustrating that the estimated sensitivity of cross-border loans to US monetary policy co-moved very closely with the degree of monetary policy divergence between the US and other advanced economies.

When it comes to the VIX, we conjecture that the shifts in both the compositional components and the behavioural components of the sensitivities of cross-border loans could be driven by the characteristics of the lending national banking systems characteristics. Lenders' capitalisation levels, size, business models and profitability affect the responsiveness of their cross-border lending to shocks. The right-hand panel of Graph 7 displays some preliminary evidence that lending banks' capitalisation levels may have been an important 
driver of the post-crisis evolution in the estimated sensitivity of cross-border bank loans to global risk.

The rest of this section provides formal empirical tests of the above hypotheses. We use the decomposition results from the previous section in order to customise our empirical frameworks for examining each of the above hypotheses. Since the compositional components component explains the majority of the shifts in sensitivities to the VIX, we examine the drivers of the post-crisis compositional shifts a cross-sectional set-up. Meanwhile, since the compositional component does not play a significant role in explaining the shifts in sensitivities to US MP, we examine the potential drivers of that set of sensitivities using a more direct panel regression approach.

\subsection{Drivers of the shifts in sensitivities to global risk}

The drivers of the shifts in sensitivities to global risk are investigated using a two-stage analysis that compares (i) the pre- and post-crisis sensitivities of individual banking systems to the VIX (the behavioural component) as well as (ii) the pre- and post-crisis shares of national banking system $i$ lenders (the compositional component). The analysis examines which banking systems characteristics and policies are associated with changes to lenderspecific sensitivities and weights during the post-crisis period.

We test for the main drivers of the shift in sensitivities to global factors by estimating specifications in which the changes in the estimated coefficients are regressed on a set of pre-crisis variables. In particular, we estimate the following regressions:

$$
\left(\beta_{2, k, \text { Post }}^{i}-\beta_{2, k, \text { Pre }}^{i}\right)=\gamma_{2}{ }^{\prime} F_{2008}^{i}+\zeta_{2}{ }^{\prime} P_{2008}^{i}+\theta_{s, k}+\varepsilon_{2, k}^{i}
$$

where $\left(\beta_{2, k, \text { Post }}^{i}-\beta_{2, k, \text { Pre }}^{i}\right)$ is the difference in the coefficients for logVIX taken from equation (4), estimated for lending country $\mathrm{i}$ and borrowing sector $k$ (banks, non-bank private sector and public sector). $\theta_{s, k}$ is vectors of borrowing sector fixed effects. The vector $F_{2008}^{i}$ includes two banking system indicators: i) the capital-to-asset ratio; ii) the average bank size. Bank capital acts as a buffer against contingencies triggered by shocks and can limit the credit effect of increased global uncertainty and volatility (Gambacorta and Shin, 2018). The vector $P_{2008}^{i}$ represents the creditor banking system prudential stance and it includes two prudential 
measures (capital requirements and loan-to-value limits) and a regulatory stringency index based on the World Bank's Bank Regulation and Supervision Survey. We use pre-break characteristics at the national banking system level in order to limit endogeneity issues. Since the dependent variable in those regressions is a function of estimated coefficients, each with an associated standard error around it, meta-regressions techniques are utilized ${ }^{21}$.

Likewise, the drivers of the shifts in lending banking systems' international lending shares ("weights") are analyzed using a similar regression specification to $\left(w_{k, \text { Post }}^{i}-w_{k, \text { Pre }}^{i}\right)$ :

$$
w_{k, \text { Post }}^{i}-w_{k, \text { Pre }}^{i}=\gamma_{w}^{\prime} F_{2008}^{i}+\zeta_{w}{ }^{\prime} P_{2008}^{i}+\theta_{w, k}+\varepsilon_{w, k}^{i}
$$

In this case, as weights represent values that have no standard error associated with them, we estimate equation (8) by OLS. We also test the robustness of the results by including in equations (7) and (8) additional pre-break banking system indicators: i) the average banks' expected default frequency; ii) the deposit-to-total funding ratio; and iii) the ratio of net interest income to total income.

The first two columns of Table 4 present the results for the determinants of the shifts in the sensitivity of international bank lending to global risk. The main determinant of the changes in the sensitivities to global risk appears to be the capitalization level of the respective creditor banking system. The better capitalized a given banking system was at the time of the structural break, the more likely it was that the sensitivity of its international lending to global risk declined during the post-crisis period.

The main drivers of the shifts in the composition of international lending (approximated by the lending weights defined above) between the pre- and the post-crisis periods are estimated per equation (8), in which the difference in lending national banking system weights before and after the crisis $\left(w_{\mathrm{k}, \text { Post }}^{i}-w_{\mathrm{k}, \text { Pre }}^{i}\right)$ is regressed on a set of pre-crisis business model indicators. The third column of Table 4 indicates that the banking systems that were more likely to gain market share during the post-crisis period were those that were

\footnotetext{
${ }^{21}$ The meta-regression allows for residual statistical heterogeneity in the results of different estimation (between-study variance) by assuming that the true effects follow a normal distribution around the linear predictor (Stanley and Jarrell, 1989). The metaregression can be formally defined as: $y_{i} \mid \theta_{i} \sim N\left(\theta_{i}, \sigma_{i}^{2}\right)$, where $\theta_{i} \sim N\left(x_{i} \beta, \tau^{2}\right)$ therefore: $y_{i} \sim N\left(x_{i} \beta, \sigma_{i}^{2}+\tau^{2}\right)$, where $\beta$ is the vector of estimated effects of study characteristics. This type of equation is estimated by weighted least-squares, in which the weight of each estimated coefficient depends inversely of its variance and corresponds to the inverse of the sum of two standard deviations $\left(\sigma^{2}, \tau^{2}\right)$.
} 
ex-ante better capitalized. The result does not change after including additional banking systems characteristics (the fourth column of the Table 4). ${ }^{22}$

\subsection{Drivers of the shifts in sensitivities to US monetary policy}

Since the compositional component does not play a significant role in explaining the shifts in sensitivities to US MP, we examine the drivers of the evolution of those sensitivities using a direct panel regression approach. More concretely, we formally examine the relevance of the degree of divergence among advanced economies' monetary policies by interacting it with the coefficients of $\triangle F F R$ in equation (2), while controlling for several lending banking system characteristics. The resulting model is:

$$
\begin{aligned}
\operatorname{GrRateY}_{t}^{j}=\beta^{\prime} & X_{t}^{j}+\left[v+\eta^{\prime} \Delta F F R_{t}\right] \text { polDiv }_{t}+\left[\varrho+\xi^{\prime} \Delta F F R_{t}\right] \text { lenderChar }_{t}^{j} \\
& +I\left(\geq T_{\text {break }}^{Y}\right)\left\{\kappa+\gamma^{\prime} X_{t}^{j}+\left[\omega+\chi^{\prime} \Delta F F R_{t}\right] \text { polDiv }_{t}\right. \\
& \left.+\left[\delta+\psi^{\prime} \Delta F F R_{t}\right] \text { lenderChar }_{t}^{j}\right\}+\mu^{j}+\varepsilon_{t}^{j}
\end{aligned}
$$

where polDiv $_{t}$ is a proxy for the monetary policy convergence between the US and other advanced economies; lenderChar ${ }_{t}^{j}$ is a vector of weighted averages of the banking system characteristics of lenders to borrowers in country $j$. As in equation (4), the weight for each creditor banking system $i, w_{t-1}^{i, j}=\frac{s_{t-1}^{i, j}}{\sum_{i} s_{t-1}^{i, j}}$ equals the respective share of the outstanding stock for which it accounts.

The results from the estimation of the above regression specification are shown in Table 5. They strongly suggest that the degree of AE monetary policy convergence played a large role in driving the post-GFC fluctuations in the estimated sensitivity of cross-border bank lending flows to US monetary policy. More concretely, the positive and highly statistically significant coefficient on the interaction term between the US monetary policy

\footnotetext{
22 We further check the robustness of the results presented in Table 4 by estimating a couple of additional alternative specifications. In the first additional set of robustness checks, we re-estimate all specifications in Table 4 while including controls for the (credit-ratings implied) implicit bailout guarantee at the national banking system level. More specifically, we construct a variable that is equal to the average difference between the "All-in" credit rating and the "Stand-alone" credit rating of each bank headquartered in a given country for which both of the above ratings are available. In the second additional set of robustness checks, we re-estimate all specifications in Table 4 while including a dummy for Germany, Japan and the US, the three national banking system with the largest changes in the international lending weights during the post-crisis period. The results generated by both of these robustness checks, which are available upon request, are qualitatively very similar to the benchmark estimates reported in Table 4.
} 
variable and the MP Divergence variable implies that the sensitivity of cross-border bank lending to US monetary policy was at or close to its peak during periods of AE monetary policy convergence. This was exactly the case during the period between the GFC and the Taper Tantrum. Once the degree of AE monetary policy convergence declined after 2013, so did the sensitivity of international lending to US monetary policy. Importantly, the statistical significance of $A E$ monetary policy convergence is robust to the inclusion of several (lenders) balance sheet characteristics, such as capitalization, profitability and the relative importance of interest income.

\section{Robustness}

We conduct several sets of robustness checks. First, all benchmark specifications are reestimated using alternative measures of US monetary policy. Second, additional controls are added to our baseline specifications. Third, alternative measures of international bond flows are used.

\subsection{Alternative measures of US monetary policy}

The baseline results for the sensitivities to US monetary policy are obtained using the Wu-Xia (2016) shadow rate measure, which is generated by a discrete time multi-factor term structure model and assumed to be a linear function of three latent variables which follow a VAR (1) process. The latent factors and the shadow rate are estimated with the extended Kalman filter.

The Wu-Xia (2016) shadow rate has established itself as the preferred measure of the US monetary policy stance during the post-crisis period. Nevertheless, it is one is several such measures, each of which has its own advantage and disadvantages (see discussion of trade-offs by Lemke and Vladu, 2017). We test the robustness of our results by using alternative measures the US monetary policy stance, re-estimating our benchmark specifications while replacing the Wu-Xia (2016) shadow rate with alternative shadow rate estimates by Krippner (2014) and by Bauer and Rudebusch (2016). Furthermore, we also conduct robustness checks using two-year Treasury bond yields instead of shadow rates. 
This allows us to test the sensitivity of our main results to replacing the model-based shadow rates with rates that are based on hard market data (Swanson and Williams (2014)).

The shadow rate of Krippner (2014) is based on a two state-variable shadow yield curve model estimated using the iterated extended Kalman filter on month-end US yield curve data from 1985 with times to maturity spanning 0.25 to 30 years. When estimating their shadow rate, Bauer and Rudebusch (2016) replace the affine short-rate specification of standard dynamic term structure models with an identical affine process for an unobserved shadow short rate. The $\mathrm{Wu}$-Xia shadow rate tends to be in between the two alternative shadow rates. Table B3 (in Annex B) reports the estimations using the two alternative shadow rates as well as two-year US Treasury bond rates, showing coefficients that are in line with the benchmark results obtained using the Wu-Xia shadow policy rate in Table 2.

\subsection{Additional controls}

Next, we further test the robustness of the results by including additional control variables in the benchmark specifications. More specifically, the following additional explanatory variables are inserted into the baseline regressions: lagged growth rates of cross-border loans or international debt securities; policy rates of the receiving country to account for the local monetary policy stance; 10-year US rates to account for yield curve effects; exchange rates vis à vis the US dollar; other advanced economy policy rates. Tables B5 and B6 in Appendix B contain the results.

Table B4 presents the results from the alternative specifications, estimated without a structural break. The sensitivities to US MP are negative and statistically significant, as in the baseline estimations. The sensitivities to the VIX are also negative and statistically significant in some, but not in all, cases. This is most likely due to the fact that the data availability constraints associated with the inclusion of the above additional control variables results in a considerable reduction (of roughly one third) in the size of the sample

Table B5 presents the results from the alternative specifications, estimated with a structural break. The results are qualitatively similar to the ones reported in Table 3 in the main text. Namely, the sensitivities to US MP increase post-GFC up to the Taper Tantrum and 
then revert back to pre-GFC levels. The sensitivities to the VIX are once again negative and statistically significant before the crisis and insignificant after the crisis.

\subsection{Alternative international bond flow measures}

Our benchmark regressions use international debt securities from the BIS IDSS as measure of international bond flows. International debt securities in the IS IDSS are defined as those issued in a market other than the local market of the country where the borrower resides (Gruić and Wooldridge, 2012). For most borrowing countries and sectors, the universe of international debt securities tends to largely overlap with the universe of debt securities held by external investors. Nevertheless, the match between the above two sets is not always perfect as securities issued in foreign markets may be purchased and held by domestic residents, and domestically issued debt securities could be bought by external investors. For robustness, the international debt securities series used in our benchmark regressions are replaced with data on portfolio debt from the Balance of Payments, using the quarterly growth rate of the respective (gross) outstanding IIP stocks. ${ }^{23}$ The estimated impacts of US monetary policy and global uncertainty on portfolio debt flows remain negative and statistically significant for aggregate flows and their main sectoral (bank and non-bank) components (Table B6 in Annex B).

\section{Conclusions}

Significant changes have occurred in the sensitivity to global factors across the two main components of global liquidity, cross-border bank loans and international debt securities. The impact of US monetary policy increased dramatically between the GFC and the 2013 Fed Taper Tantrum and then reverted back to pre-crisis levels. By contrast, the responsiveness of cross-border loan flows to global risk conditions declined significantly throughout the postcrisis period.

The post-crisis fluctuations in the sensitivity of international bank lending flows to US monetary policy were driven mainly by increases in the sensitivities of individual banking

\footnotetext{
${ }^{23}$ The exact series from the Balance of Payments is 'Portfolio Investment Debt, Liabilities' (Line 79led).
} 
systems. The latter increases were, in turn, largely driven by the convergence in advanced economy monetary policies that took place in the immediate aftermath of the GFC. As the monetary policies of advanced economies started to diverge in 2013, these transitory effects gradually weakened.

Conversely, compositional changes were the main drivers of the decline in the sensitivity of international bank lending to global risk conditions. National banking systems that were ex-ante better capitalized experienced larger increases in their international lending shares and smaller increases in sensitivities to global risk. This combination resulted in a sharp decrease in the overall sensitivity of international bank lending to global risk conditions. Since both of the above developments are likely to be persistent, so are the declines in sensitivities to global risk.

Overall, our analysis demonstrates the dynamism in global liquidity drivers, as well as in international monetary policy spillovers and risk effects. This dynamism, not previously explored in depth, is relevant for debates on the use and potential efficacy of capital regulation and the autonomous use of monetary policy. Regardless of the degree of integration with international financial markets, funding flows may be more responsive when policy cycles of advanced economies are more aligned. Funding flows through global banks appear to be less volatile for banks with greater capital buffers and for larger banks.

Last but not least, the results demonstrate that initiatives to make banking systems more robust in advanced countries, for example through prudential instrument changes and policies aimed at boosting capitalisation and stable funding levels, have had the positive side effect of reducing the amplitude of fluctuations in some forms of international capital flows to both advanced and emerging markets. Such policies can complement borrower country macro-prudential policies and capital flow management instruments. Open questions still remain around the behaviour of international debt securities and await both richer data and more research on these financing flows. 


\section{References}

Acharya, V. V., P. Shnabl and G. Suarez (2013) "Securitization without risk transfer," Journal of Financial Economics, 107(3), 515-536.

Amiti M., P. McGuire and D. Weinstein (2017) "Supply and demand-side factors in global bank credit", BIS Working Papers 639, Bank for International Settlements.

Avdjiev, S., C. Koch, P. McGuire and G. von Peter (2017) "International prudential policy spillovers: A Global Perspective", International Journal of Central Banking, 13(2), 5-33.

Bai, J. (1994) "Least squares estimation of a shift in linear processes", Journal of Time Series Analysis, 15 (5), 453-472.

Bai, J. (1997) "Estimation of a change point in multiple regression models", Review of Economics and Statistics, 79 (4), 551-563.

Bank for International Settlements (2011a) "Global liquidity - concept, measurement and policy implications," CGFS Papers, Bank for International Settlements, n 45.

Bank for International Settlements (2011b), "Global liquidity: insights from the BIS statistics", note for a meeting of the G20 Sub-Working Group on global liquidity management, 25 March.

Bank for International Settlements (2015) "Introduction to BIS statistics." BIS Quarterly Review, September, 49-56.

Bauer, M. D. and G. D. Rudebusch (2016) "Monetary Policy Expectations at the Zero Lower Bound," Journal of Money, Credit and Banking, 48(7), 1439-1465.

Bekaeart, G., E. Engstrom, and N. Xu (2017) "The Time Variation in Risk Appetite and Uncertainty", Columbia Business School Research Paper, No. 17-108.

Benetrix, A., R. McCauley, P. McGuire, and G. von Peter (2019) "Financial Deglobalization in Banking?" Journal of International Money and Finance vol 94 (June), 116-131.

Berlin, M. and L. Mester (1999) "Deposits and relationship lending", Review of Financial Studies, 12 (3), 579-607.

Brei, M., L. Gambacorta, and G. von Peter (2013) "Rescue Packages and Bank Lending", Journal of Banking and Finance, 37(2), 490-505.

Broner, F., T. Didier, A. Erce, and S. L. Schmukler (2013) "Gross Capital Flows: Dynamics and Crises." Journal of Monetary Economics 60(1), 113-133.

Bruno, V. and H. S. Shin (2015a) "Cross-border banking and global liquidity" Review of Economic Studies, 82(2), 535-564.

Bruno, V. and H. S. Shin (2015b) "Capital flows and the risk-taking channel of monetary policy" Journal of Monetary Economics, 71, 119-132.

Buch, C.M., M. Bussiere, L.S. Goldberg, and R. Hills (2019) "The International Transmission of Monetary Policy" Journal of International Money and Finance, 91 (March), 29-48.

Buch C. M. and L. S. Goldberg (2015) "International Banking and Liquidity Risk Transmission: Lessons from Across Countries," IMF Economic Review, International Monetary Fund, 63(3), 377-410.

Buch, C. M. and L. S. Goldberg (2017) "Cross-border prudential policy spillovers: How much? How important? Evidence from the international banking research network," International Journal of Central Banking, 505-558 (March).

Bussière, M., J. Schmidt and N. Valla (2018) "International Financial Flows in the New Normal: Key Patterns (and Why We Should Care)", in: Ferrara L., Hernando I., Marconi D. (eds) International Macroeconomics in the Wake of the Global Financial Crisis. Financial and Monetary Policy Studies, vol 46. Springer.

Carrion-i-Silvestre, J.L. and A. Sansó (2006) "Testing the null of cointegration with structural breaks", Oxford Bulletin of Economics and Statistics, 68 (5), 623-646. 
Cerutti, E. and S. Claessens (2017) "The Great Cross-Border Bank Deleveraging: Supply Constraints and Intra-Group Frictions," Review of Finance, 21 (1), 201-236.

Cerutti, E., R. Correa, E. Fiorentino, E. Segalla (2017) "Changes in prudential policy instruments: a new cross-country database". International Journal of Central Banking, (March) 477-503.

Cerutti, E., S. Claessens and L. Ratnovski (2017) "Global Liquidity and Drivers of Cross- Border Bank Flows." Economic Policy 32 (89): 81-125.

Cerutti, E., S. Claessens S. and A.K. Rose (2017) "How important is the financial cycle? Evidence from capital flows", BIS Working Papers 661.

Cetorelli, N. and L. S. Goldberg (2012a) "Liquidity management of U.S. Global Banks: Internal Capital Markets in the Great Recession". Journal of International Economics, 88(2), 299-311.

Cetorelli, N. and L. S. Goldberg (2012b) "Banking Globalization and Monetary Transmission," Journal of Finance, 67(5), 1811-1843.

Chinn, M. D. and H. Ito (2008) "A New Measure of Financial Openness". Journal of Comparative Policy Analysis, 10(3), 309-322.

Chuhan, P., S. Claessens and N. Mamingi (1998) "Equity and Bond Flows to Latin America and Asia: the Role of Global and Country Factors." Journal of Development Economics 55(2), 439463.

Chung, K., J-E Lee, E. Loukoianova, H. Park and H. S. Shin (2015)"Global liquidity through the lens of monetary aggregates," Economic Policy, 30(82), 231-290.

Cornett, M. M., J. J. McNutt, P. E. Strahan and H. Tehranian (2011) "Liquidity risk management and credit supply in the financial crisis," Journal of Financial Economics, 101(2), 297-312.

Damar H. E. and A. Mordel (2017) "International Banking and Cross-Border Effects of Regulation: Lessons from Canada," International Journal of Central Banking, 13(2), 35-64.

De Grauwe, P. and Y. Ji (2013) "Self-fulfilling crises in the Eurozone: An empirical test" Journal of International Money and Finance, 34, 15-36.

De Haas, R. and N. Van Horen (2013) "Running for the Exit? International Bank Lending During a Financial Crisis" Review of Financial Studies, 26 (1), 244-285.

Farhi, E. and J. Tirole (2016) "Deadly Embrace: Sovereign and Financial Balance Sheets Doom Loops" Review of Economic studies, forthcoming.

Fernandez-Arias, E. (1996) "The new wave of private capital inflows: Push or pull?," Journal of Development Economics, 48(2), 389-418.

Forbes, K. J. and F. E. Warnock (2012a) "Capital flow waves: Surges, stops, flight, and retrenchment," Journal of International Economics, 88(2), 235-251.

Forbes, K. J. and F. E. Warnock (2012b) "Debt- and Equity-Led Capital Flow Episodes", in Capital Mobility and Monetary Policy, edited by Miguel Fuentes and Carmen M. Reinhart. Santiago: Central Bank of Chile. Also available as NBER Working Paper 18329.

Forbes, K. J., M. Fratzscher and R. Straub (2015) "Capital-flow management measures: What are they good for?", Journal of International Economics, 96(S1), S76-S97.

Forbes, K. J., D. Reinhardt and T. Wieladek (2017) "The Spillovers, Interactions, and (Un)Intended Consequences of Monetary and Regulatory Policies", Journal of Monetary Economics, Volume 85, Pages 1-136 January.

Gambacorta, L. and D. Marques (2011) "The bank lending channel: lessons from the crisis", Economic Policy, 26(66), 135-82.

Gambacorta, L. and A: van Rixtel (2013) "Structural bank regulation initiatives: Approaches and implications", BIS Working Papers 412.

Gambacorta, L. and H. S. Shin (2018) "Why bank capital matters for monetary policy," Journal of Financial Intermediation, forthcoming.

Ghosh A. R. and J. D. Ostry (1994) "Export Instability and the External Balance in Developing Countries," IMF Staff Papers, 41(2), 214-235. 
Goldberg L. S. (2013) "Banking Globalization, Transmission, and Monetary Policy Autonomy," Sveriges Riksbank Economic Review, November, 161-193.

Gruić, B. and P. Wooldridge (2012) "Enhancements to the BIS debt securities statistics", BIS Quarterly Review, December, 63-76.

Ha, J., M.A. Kose, C. Otrok and E. Prasad (2017) Global Macro Financial Cycles and Spillovers. Manuscript, The World Bank.

Harbord, R. and J. Higgins (2008) "Meta regression in Stata", The Stata Journal, 8(4), 493-519.

Huettner, F. and M. Sunder (2012) "Axiomatic arguments for decomposing goodness of fit according to Shapley and Owen values," Electronic Journal of Statistics, 6, 1239-1250.

Khatiwada, S. (2017) "Quantitative Easing by the Fed and International Capital Flows", Graduate Institute Geneva Working Paper, January.

Klein, M. W. and J. C. Shambaugh (2008) "The dynamics of exchange rate regimes: Fixes, floats, and flips," Journal of International Economics, 75(1), 70-92.

Koepke, R. (2015) "What Drives Capital Flows to Emerging Markets? A Survey of the Empirical Literature." IIF Working Paper.

Krippner, L. (2014) "Measuring the stance of monetary policy in conventional and unconventional environments", CAMA Working Paper 6.

Kurozumi, E. (2002) "Testing for stationarity with a break", Journal of Econometrics, 108(1), 63-99.

Lamers M., F. Mergaerts, E. Meuleman and R. Vander Vennet (2016) "The Trade-Off between Monetary Policy and Bank Stability," National Bank of Belgium Working Paper 308.

Leiderman L., C. Reinhart and G. Calvo (1993) "Capital Inflows and Real Exchange Rate Appreciation in Latin America; The Role of External Factors," IMF Staff Papers 108-151.

Lemke W. and A. L. Vladu (2017) "Below the zero lower bound: a shadow-rate term structure model for the euro area," ECB Working Paper Series 1991.

Martinez-Miera D. and R. Repullo (2017) "Search for Yield" Econometrica, Econometric Society, vol. 85, pages 351-378, March..

McCauley, R., P. McGuire and V. Sushko (2015): "Global dollar credit: links to US monetary policy and leverage", Economic Policy, 30(82), 187-229.

Milesi-Ferretti, G., and C. Tille (2011) "The Great Retrenchment: International Capital Flows during the Global Financial Crisis." Economic Policy 26(66), 289-346.

Miranda-Agrippino, S. and H. Rey (2015) "US Monetary Policy and the Global Financial Cycle", NBER Working Paper 21722.

Obstfeld, M., J. Ostry, and M. Qureshi. 2018. "Global Financial Cycles and the Exchange Rate Regime," CEPR Discussion Paper 12696.

Obstfeld, M., J. C. Shambaugh and A. M. Taylor (2005) "The Trilemma in History: Tradeoffs Among Exchange Rates, Monetary Policies, and Capital Mobility," The Review of Economics and Statistics, 87(3), 423-438.

Passari, E. and H. Rey (2015) "Financial Flows and the International Monetary System." The Economic Journal 125, 675-698.

Portes, R. and H. Rey (2005) "The Determinants of Cross-Border Equity Flows," Journal of International Economics, 65(2), 269-296.

Rey, H. (2013) "Dilemma not Trilemma: The Global Financial Cycle and Monetary Policy Independence", Proceedings of the Federal Reserve Bank of Kansas City Economic Symposium at Jackson Hole.

Roengpitya R., N. Tarashev and K. Tsatsaronis (2017) "Bank business models: popularity and performance," BIS Working Paper Series, 682.

Rose, A. and T. Wieladek (2014) "Financial Protectionism? First Evidence", Journal of Finance, vol. 69(5), pages 2127-2149, October. 
Schularick, M. and A.M. Taylor (2012) "Credit Booms Gone Bust: Monetary Policy, Leverage Cycles, and Financial Crises, 1870-2008." American Economic Review 102 (April), 1029-61.

Shin, H. S. (2013) "The Second Phase of Global Liquidity and Its Impact on Emerging Economies". Keynote address at the Federal Reserve Bank of San Francisco Asia Economic Policy Conference, November 3-5.

Shin, H. S. (2016) "The bank/capital markets nexus goes global", speech at the London School of Economics and Political Science, London, 15 November.

Stanley, T. D. and S. B. Jarrell (1989) "Meta-regression analysis: A quantitative method of literature surveys", Journal of Economic Surveys, 19(3) 299-308.

Swanson, E. T. and J. C. Williams (2014) "Measuring the Effect of the Zero Lower Bound on Medium- and Longer-Term Interest Rates." American Economic Review, 104 (10): 3154-85.

Taylor, M. P. and L. Sarno (1997) "Capital Flows to Developing Countries: Long-and Short- Term Determinants." The World Bank Economic Review, 11(3), 451-470.

Wu, J. C. and F. D. Xia (2016) "Measuring the Macroeconomic Impact of Monetary Policy at the Zero Lower Bound," Journal of Money, Credit and Banking, Blackwell Publishing, 48(3), 253291. 
Table 1 - Typical Lenders and Borrowers

\begin{tabular}{|c|c|c|c|}
\hline & Typical Lenders & Typical Borrowers & Notes \\
\hline $\begin{array}{l}\text { Cross-border } \\
\text { loans (XBL) to } \\
\text { banks }\end{array}$ & $\begin{array}{l}\text { Internationally-active } \\
\text { banks }\end{array}$ & Banks (all sizes) & $\begin{array}{l}\text { Interbank market } \\
\text { (unsecured and repo) }\end{array}$ \\
\hline $\begin{array}{l}\text { Cross-border } \\
\text { loans (XBL) to } \\
\text { non-banks }\end{array}$ & $\begin{array}{c}\text { Internationally-active } \\
\text { banks }\end{array}$ & $\begin{array}{c}\text { Large non-financial } \\
\text { corporates; } \\
\text { exporting/importing firms; } \\
\text { Leveraged non-bank financials }\end{array}$ & $\begin{array}{c}\text { Syndicated loan market; } \\
\text { trade credit; } \\
\text { project financing }\end{array}$ \\
\hline $\begin{array}{l}\text { International } \\
\text { debt securities } \\
\text { (IDS) issued by } \\
\text { banks }\end{array}$ & $\begin{array}{c}\text { Pension funds; } \\
\text { Insurance companies; } \\
\text { MMMFs; } \\
\text { Hedge funds }\end{array}$ & Large and mid-sized banks & $\begin{array}{c}\text { Smaller investor base than } \\
\text { for IDS issued by non- } \\
\text { banks }\end{array}$ \\
\hline $\begin{array}{c}\text { International } \\
\text { debt securities } \\
\text { (IDS) issued by } \\
\text { non-banks }\end{array}$ & $\begin{array}{c}\text { Pension funds; } \\
\text { Insurance companies; } \\
\text { MMFs; Hedge funds }\end{array}$ & $\begin{array}{l}\text { Non-financial corporates; } \\
\text { governments; } \\
\text { Insurance companies }\end{array}$ & $\begin{array}{l}\text { Broader investor base than } \\
\text { for IDS issued by banks }\end{array}$ \\
\hline
\end{tabular}

Table 2 - Locational baseline regressions (by borrowing country)

\begin{tabular}{|c|c|c|c|c|c|c|}
\hline \multirow[b]{2}{*}{ Explanatory variables } & \multicolumn{3}{|c|}{$\begin{array}{l}\text { Dependent variable: } \\
\Delta \text { Cross-border loans }^{\dagger}\end{array}$} & \multicolumn{3}{|c|}{$\begin{array}{c}\text { Dependent variable: } \\
\Delta \text { International debt securities }\end{array}$} \\
\hline & All & to banks & to non-banks & All & by banks & $\begin{array}{c}\text { by non- } \\
\text { banks }\end{array}$ \\
\hline$\Delta$ Fed funds rate (1) & $\begin{array}{c}-1.95 * * * \\
(0.38)\end{array}$ & $\begin{array}{c}-2.48 * * * \\
(0.58)\end{array}$ & $\begin{array}{c}-1.86 * * * \\
(0.34)\end{array}$ & $\begin{array}{c}-1.76^{* * *} \\
(0.66)\end{array}$ & $\begin{array}{c}-2.26^{* *} \\
(0.95)\end{array}$ & $\begin{array}{c}-1.44^{* *} \\
(0.69)\end{array}$ \\
\hline Log(VIX) & $\begin{array}{l}-2.75^{* * *} \\
(0.59)\end{array}$ & $\begin{array}{c}-2.51 * * * \\
(0.96)\end{array}$ & $\begin{array}{c}-3.10 * * * \\
(0.62)\end{array}$ & $\begin{array}{c}-2.31 * * * \\
(0.75)\end{array}$ & $\begin{array}{l}-5.22 * * * \\
(1.77)\end{array}$ & $\begin{array}{l}-1.49 * \\
(0.83)\end{array}$ \\
\hline$\Delta$ Real GDP & $\begin{array}{c}0.54^{* * * *} \\
(0.09)\end{array}$ & $\begin{array}{c}0.57 * * * \\
(0.12)\end{array}$ & $\begin{array}{l}0.50 * * * \\
(0.08)\end{array}$ & $\begin{array}{c}0.09 \\
(0.10)\end{array}$ & $\begin{array}{l}0.20 \\
(0.24)\end{array}$ & $\begin{array}{c}0.08 \\
(0.13)\end{array}$ \\
\hline$\Delta$ Sovereign rating (2) & $\begin{array}{l}2.80^{* * *} \\
(1.06)\end{array}$ & $\begin{array}{c}4.37 * * * \\
(1.40)\end{array}$ & $\begin{array}{c}0.02 \\
(0.84)\end{array}$ & $\begin{array}{c}0.56 \\
(0.85)\end{array}$ & $\begin{array}{l}-1.50 \\
(2.82)\end{array}$ & $\begin{array}{c}0.30 \\
(1.05)\end{array}$ \\
\hline Chinn-Ito index (3) & $\begin{array}{l}-1.35 \\
(1.79)\end{array}$ & $\begin{array}{l}-3.03 \\
(2.87)\end{array}$ & $\begin{array}{c}0.30 \\
(1.85)\end{array}$ & $\begin{array}{c}8.11^{* * * *} \\
(2.89)\end{array}$ & $\begin{array}{c}10.72^{* *} \\
(4.61)\end{array}$ & $\begin{array}{c}4.87 \\
(3.03)\end{array}$ \\
\hline$\Delta$ Real global GDP & $\begin{array}{c}0.50^{* * *} \\
(0.16)\end{array}$ & $\begin{array}{c}0.81^{* * *} \\
(0.24)\end{array}$ & $\begin{array}{c}0.34 * * \\
(0.16)\end{array}$ & $\begin{array}{c}0.00 \\
(0.26)\end{array}$ & $\begin{array}{c}-0.18 \\
(0.79)\end{array}$ & $\begin{array}{l}-0.15 \\
(0.30)\end{array}$ \\
\hline Observations & 3,327 & 3,327 & 3,327 & 3,327 & 2,961 & 3,326 \\
\hline R-squared & 0.11 & 0.07 & 0.08 & 0.05 & 0.03 & 0.03 \\
\hline $\begin{array}{l}\text { Notes: The sample inclu } \\
\text { include a full set of co } \\
\text { borrowers in country j. } \\
\text { Wu-Xia Shadow rate for } \\
\text { agencies (S\&P, Moody’s }\end{array}$ & $\begin{array}{l}\text { larterly data } \\
\text { fixed effects } \\
\text { l by borrowe } \\
\text { eriod 2009:c } \\
\text { itch). (3) Me }\end{array}$ & $\begin{array}{l}64 \text { recipi } \\
\text { obust stan } \\
\text { n country } \\
\text { - 2015:Q4 } \\
\text { re of finan }\end{array}$ & $\begin{array}{l}\text { countries over } \\
\text { errors in pare } \\
\text { Effective fede } \\
\text { Long term for } \\
\text { openness devel }\end{array}$ & $\begin{array}{l}\text { period } 200 \\
\text { eses. } * * * \\
\text { funds rate } \\
\text { n currency }\end{array}$ & $\begin{array}{l}1-2015: \mathrm{Q} 4 \\
.01, * * \mathrm{p}<0 . \\
\text { he period } 20 \\
\text { ereign rating, } \\
\text { Ito (2008). }\end{array}$ & $\begin{array}{l}\text { regressio } \\
\mathrm{p}<0.1 .^{\dagger} \\
-2008: \mathrm{Q} \\
\text { age across }\end{array}$ \\
\hline
\end{tabular}


Table 3 - Locational baseline regressions (by borrowing country) with a structural break

\begin{tabular}{|c|c|c|c|}
\hline & $\begin{array}{c}\text { Dependent variable: } \\
\Delta \text { Cross-border loans } †\end{array}$ & $\begin{array}{c}\text { Dependent variable: } \\
\Delta \text { International debt securities } \ddagger\end{array}$ & $\begin{array}{c}\text { Dependent variable: } \\
\Delta \text { Total cross-border flows } \\
\text { (loans and debt securities) }\end{array}$ \\
\hline \multicolumn{4}{|l|}{ Pre } \\
\hline$\Delta F F(1)$ & $\begin{array}{c}-3.19 * * * \\
(0.49)\end{array}$ & $\begin{array}{l}-1.42 \\
(1.03)\end{array}$ & $\begin{array}{c}-2.07 * * * \\
(0.36)\end{array}$ \\
\hline VIX (2) & $\begin{array}{c}-3.94 * * * \\
(0.94)\end{array}$ & $\begin{array}{l}-1.09 \\
(1.28)\end{array}$ & $\begin{array}{c}-3.11^{* * *} \\
(0.67)\end{array}$ \\
\hline \multicolumn{4}{|c|}{ Post - up to 2013:Q1 } \\
\hline$\Delta F F(1)$ & $\begin{array}{c}-8.07 * * * \\
(1.34) \\
-2.68 * * \\
(1.07) \\
\end{array}$ & $\begin{array}{c}-8.17 * * * \\
(2.51) \\
-3.07 * * \\
(1.48) \\
\end{array}$ & $\begin{array}{c}-7.96 * * * \\
(1.00) \\
-3.14 * * * \\
(0.83) \\
\end{array}$ \\
\hline \multicolumn{4}{|c|}{ Post - up to 2015:Q4 } \\
\hline$\Delta \mathrm{FF}(1)$ & $\begin{array}{c}-3.68 * * * \\
(0.71)\end{array}$ & $\begin{array}{c}-5.19 * * * \\
(0.92)\end{array}$ & $\begin{array}{c}-4.37 * * * \\
(0.47)\end{array}$ \\
\hline VIX (2) & $\begin{array}{l}-0.32 \\
(0.81) \\
\end{array}$ & $\begin{array}{l}-1.55 \\
(1.06) \\
\end{array}$ & $\begin{array}{l}-1.18^{*} \\
(0.60)\end{array}$ \\
\hline \multicolumn{4}{|c|}{$\begin{array}{l}\text { Notes: The sample includes quarterly data for } 64 \text { recipient countries over the period 2000:Q1 - 2015:Q4. Robust standard } \\
\text { errors in parentheses. }{ }^{* *} \mathrm{p}<0.01, * * \mathrm{p}<0.05, * \mathrm{p}<0.1 \text {. } \dagger \text { to borrowers in country j. } \ddagger \text { issued by borrowers in country j. (1) } \\
\text { Effective federal funds rate for the period 2000:Q1 }-2008: \mathrm{Q} 4 \text {, Wu-Xia Shadow rate for the period 2009:Q1 - 2015:Q4. } \\
\text { (2) Log(VIX). The regressions include } \Delta \text { Real GDP, } \Delta \text { Sovereign Ratings, Chinn-Ito Index, } \Delta \text { Real Global GDP and their } \\
\text { interaction with a break dummy that takes value } 1 \text { after the break date (2009:Q1). The regressions also include a full set of } \\
\text { country fixed effects. }\end{array}$} \\
\hline
\end{tabular}


Table 4 - Drivers of the shifts in lender-specific sensitivities and weights

\begin{tabular}{|c|c|c|c|c|}
\hline \multirow[t]{2}{*}{ Explanatory variables } & \multicolumn{2}{|c|}{$\begin{array}{c}\text { Dependent variable: } \\
\text { Structural change in the } \\
\text { coefficient for Log(VIX) } \\
\beta_{2}^{\text {Post }}-\beta_{2}^{\text {Pre }}\end{array}$} & \multicolumn{2}{|c|}{$\begin{array}{c}\text { Dependent variable: } \\
\text { Change in the lending national } \\
\text { banking system weights } \\
w^{\text {Post }}-w^{\text {Pre }}\end{array}$} \\
\hline & (I) & (II) & (III) & (IV) \\
\hline Pre-break capital ratio (2008) & $\begin{array}{l}0.706 * * \\
(0.310)\end{array}$ & $\begin{array}{l}0.788 * * \\
(0.334)\end{array}$ & $\begin{array}{l}0.189 * * \\
(0.093)\end{array}$ & $\begin{array}{l}0.205^{* *} \\
(0.100)\end{array}$ \\
\hline Pre-break average bank size (2008) & $\begin{array}{r}1.194 \\
(0.904)\end{array}$ & $\begin{array}{r}1.369 \\
(0.921)\end{array}$ & $\begin{array}{l}0.507 * \\
(0.292)\end{array}$ & $\begin{array}{r}0.464 \\
(0.297)\end{array}$ \\
\hline $\begin{array}{l}\text { Prudential measures and regulatory } \\
\text { stringency index (1) }\end{array}$ & yes & yes & yes & yes \\
\hline Other controls (2) & no & yes & no & yes \\
\hline Sectoral fixed effects & yes & yes & yes & yes \\
\hline Observations & 87 & 87 & 87 & 87 \\
\hline $\mathrm{Q}(3)$ & 240.8 & 230.9 & & \\
\hline Degrees of Freedom test Q & 79 & 76 & & \\
\hline $\mathrm{I}^{2}(4)$ & 0.672 & 0.671 & & \\
\hline$\tau^{2}(5)$ & 30.02 & 30.92 & & \\
\hline Adjusted R-squared & 0.245 & 0.266 & 0.097 & 0.119 \\
\hline
\end{tabular}

Note: Coefficients are obtained from the baseline model with structural breaks. This model is estimated for each of the available 29 lending countries (we excluded South Korea for which data are not available in the pre-break period) and for three different borrowers: banks, public sector and non-banks. We obtain therefore $29 * 3=87$ observations. The lending national banking system weights are expressed in percentage terms. Robust standard errors in parentheses $* * * \mathrm{p}<0.01, * * \mathrm{p}<0.05, * \mathrm{p}<0.1$. (1) Prudential measures include loan-to-value ratio caps and capital requirements. The regulatory stringency index is based on the World Bank's Bank Regulation and Supervision Survey. The index takes a value between 0 (least stringent) and 1 (most stringent) based on 18 questions about bank capital requirements, the legal powers of supervisory agencies, etc. (2) They include the following prebreak average banking system characteristics: expected default frequency, deposit to total asset ratio and net interest income over total income. (3) The Q Measure evaluates the level of homogeneity/heterogeneity among studies. It is calculated as the weighted squared difference of the estimated effects with respect to the mean. The statistical distribution of this measure follows a $\chi^{2}$ distribution. The null hypothesis of the test assumes homogeneity in the effect sizes. (4) This percentage represents the magnitude of the level of heterogeneity in effect sizes and it is defined as the percentage of the residual variation that it is attributable to between study heterogeneity. It is defined as the difference between the $\mathrm{Q}$ measure and the degrees of freedom divided by the $\mathrm{Q}$ measure. Although there can be no absolute rule for when heterogeneity becomes important, Harbord and Higgins (2008) tentatively suggest adjectives of low for $\mathrm{I}^{2}$ values between $25 \%$ and $50 \%$, moderate for $50 \%-75 \%$ and high for values larger than $75 \%$. (5) $\tau^{2}$ is a measure of population variability in effect sizes. It depends positively on the observed heterogeneity $(\mathrm{Q}$ measure) and its difference with respect to the degrees of freedom. The expected value of Q measure under the null hypothesis of homogeneity is equal to the degrees of freedom; a homogeneous set of studies will result in this statistic equal to zero. Under the presence of heterogeneity this estimate should be different from zero. 
Table 5 Monetary Policy Divergence and Time Varying Sensitivities to US Monetary Policy

\begin{tabular}{|c|c|c|c|c|c|c|c|c|}
\hline \multirow{2}{*}{$\begin{array}{l}\text { Explanatory variables } \\
\text { Post }\end{array}$} & \multicolumn{4}{|c|}{$\begin{array}{c}\text { Dependent variable: } \\
\Delta \text { Cross-border loans } \dagger\end{array}$} & \multicolumn{4}{|c|}{$\begin{array}{c}\text { Dependent variable: } \\
\Delta \text { International debt securities } \ddagger\end{array}$} \\
\hline & & & & & & & & \\
\hline$\Delta \mathrm{FF}(1)$ & $\begin{array}{c}-8.988 * * * \\
(1.874)\end{array}$ & $\begin{array}{l}-13.26 * * \\
(5.736)\end{array}$ & $\begin{array}{c}-8.603 * * * \\
(2.081)\end{array}$ & $\begin{array}{l}-7.077 \\
(15.75)\end{array}$ & $\begin{array}{l}-5.674 * * \\
(2.633)\end{array}$ & $\begin{array}{l}-21.10 * * \\
(8.419)\end{array}$ & $\begin{array}{c}-8.175^{* * *} \\
(3.126)\end{array}$ & $\begin{array}{l}-10.73 \\
(20.79)\end{array}$ \\
\hline $\log (\mathrm{VIX})$ & $\begin{array}{l}-0.401 \\
(0.828)\end{array}$ & $\begin{array}{l}-0.385 \\
(0.828)\end{array}$ & $\begin{array}{l}-0.425 \\
(0.823)\end{array}$ & $\begin{array}{l}-0.407 \\
(0.823)\end{array}$ & $\begin{array}{l}-2.106^{*} \\
(1.169)\end{array}$ & $\begin{array}{l}-2.042 * \\
(1.169)\end{array}$ & $\begin{array}{l}-2.040 * \\
(1.172)\end{array}$ & $\begin{array}{l}-2.097^{*} \\
(1.175)\end{array}$ \\
\hline$\Delta \mathrm{FF}(1) *$ MPDivergence $(2)$ & $\begin{array}{c}7.248^{* * *} \\
(2.339)\end{array}$ & $\begin{array}{c}7.059 * * * \\
(2.326)\end{array}$ & $\begin{array}{c}7.456 * * * \\
(2.456)\end{array}$ & $\begin{array}{c}7.197 * * * \\
(2.250)\end{array}$ & $\begin{array}{c}1.989 \\
(2.656)\end{array}$ & $\begin{array}{c}1.294 \\
(2.677)\end{array}$ & $\begin{array}{c}0.817 \\
(2.817)\end{array}$ & $\begin{array}{c}2.129 \\
(2.653)\end{array}$ \\
\hline Lenders’ capitalization (3) & no & yes & no & no & no & yes & no & no \\
\hline Lenders’ profitability (4) & no & no & yes & no & no & no & yes & no \\
\hline Lenders' interest margins (5) & no & no & no & yes & no & no & no & yes \\
\hline Borrowing-country FE & yes & yes & yes & yes & yes & yes & yes & yes \\
\hline Observations & 3,377 & 3,327 & 3,327 & 3,327 & 3,377 & 3,327 & 3,327 & 3,327 \\
\hline R-squared & 0.168 & 0.172 & 0.181 & 0.176 & 0.071 & 0.075 & 0.081 & 0.074 \\
\hline \multicolumn{9}{|c|}{ 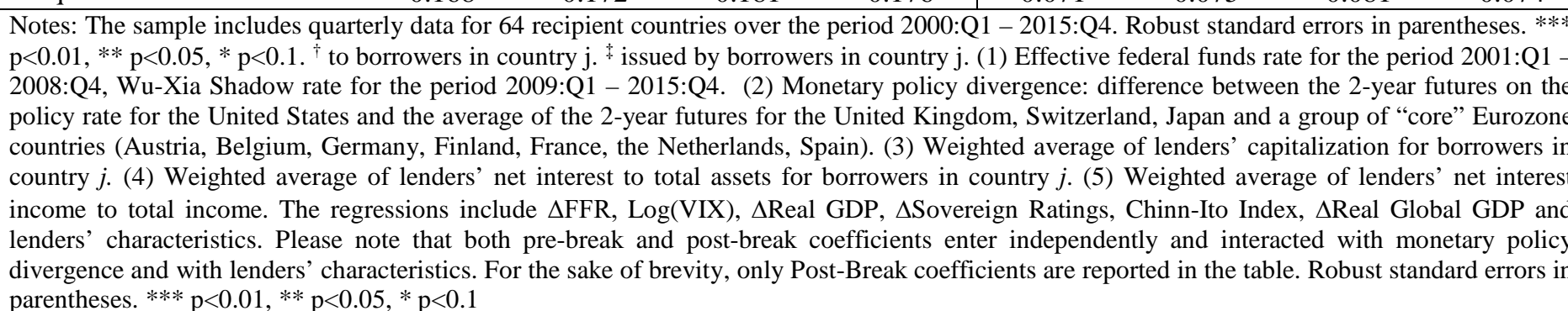 } \\
\hline
\end{tabular}


External debt flows, all borrowers

Four-quarter moving average of quarterly growth rates, in per cent

Graph 1

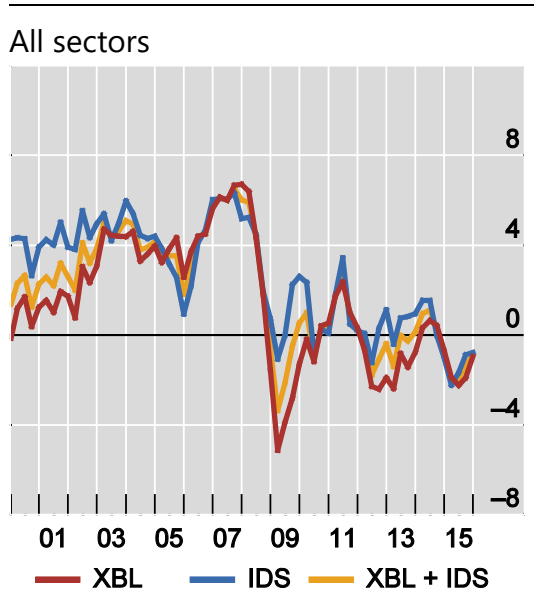

Banks

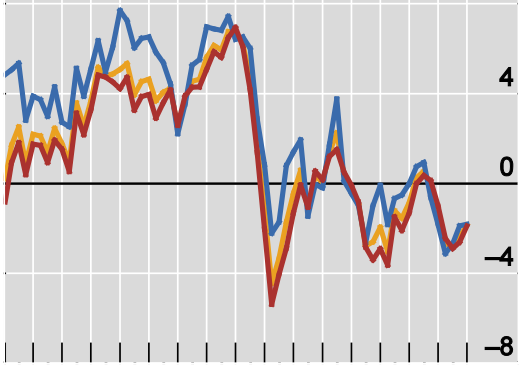

$\begin{array}{llllllll}01 & 03 & 05 & 07 & 09 & 11 & 13 & 15\end{array}$
Non-banks

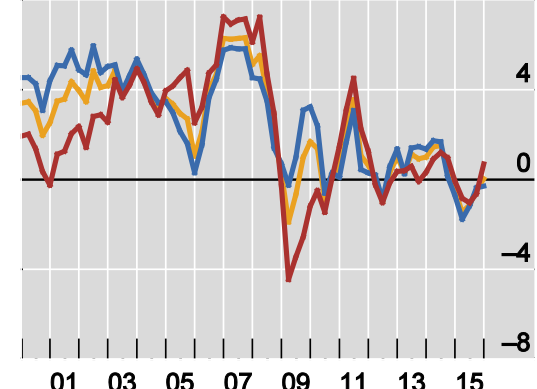

$\mathrm{XBL}=$ Cross-border loans: Quarterly Growth Rate $\mathrm{t}=$ (Outstanding Stock $/$ Outstanding Stockt-1)-1; IDS = International Debt Securities: Quarterly Growth Ratet $=$ (Outstanding Stockt / Outstanding Stockt-1)-1.

Sources: BIS Locational Banking Statistics by residence; BIS International Debt Securities Statistics.

US policy rates and measures of global risk conditions

Graph 2

US policy rates

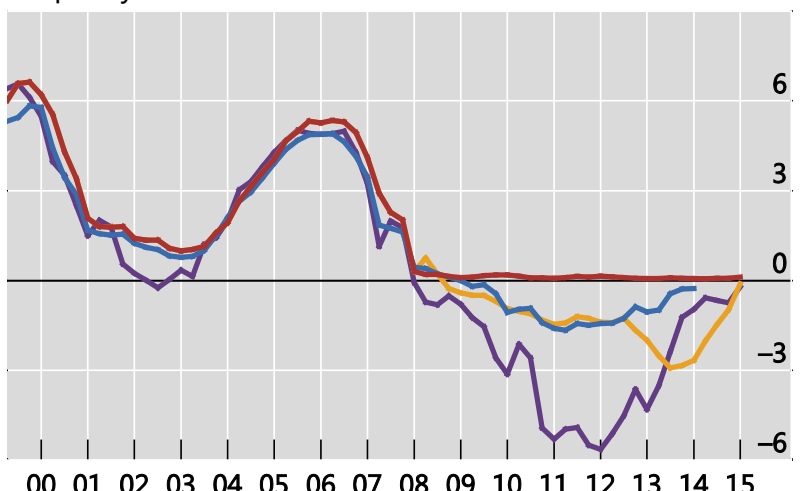

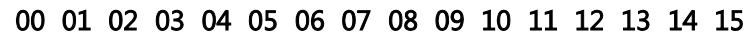

\section{Bauer-Rudebusch ${ }^{1}=$ Wu-Xia Krippner} Effective fed funds rate
Alternative measures of global risk conditions

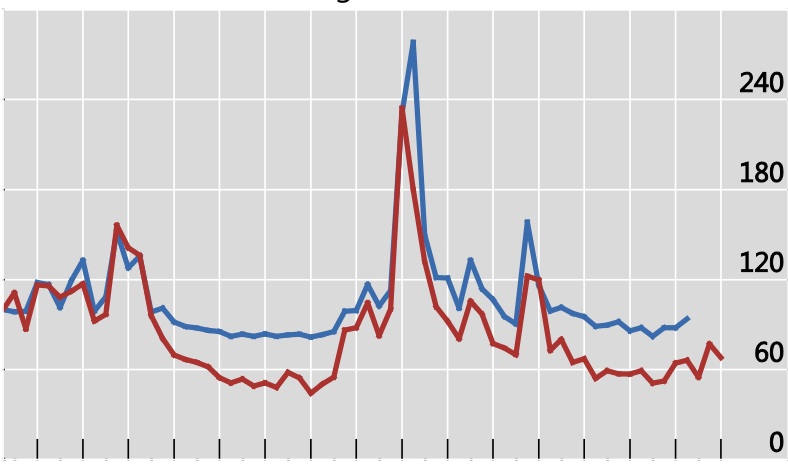

$\begin{array}{lllllllllllllll}01 & 02 & 03 & 04 & 05 & 06 & 07 & 08 & 09 & 10 & 11 & 12 & 13 & 14 & 15\end{array}$

- VIX Beakeart, Engstorm and Xu (2017)

1 Median of 12 shadow rate estimates.

Sources: Bauer and Rudebusch (2016); Bekaeart, Engstrom and Xu (2017); Krippner (2014); Wu and Xia (2015); Datastream. 


\section{AE monetary policy divergence}

2-year futures on the policy rate

Graph 3

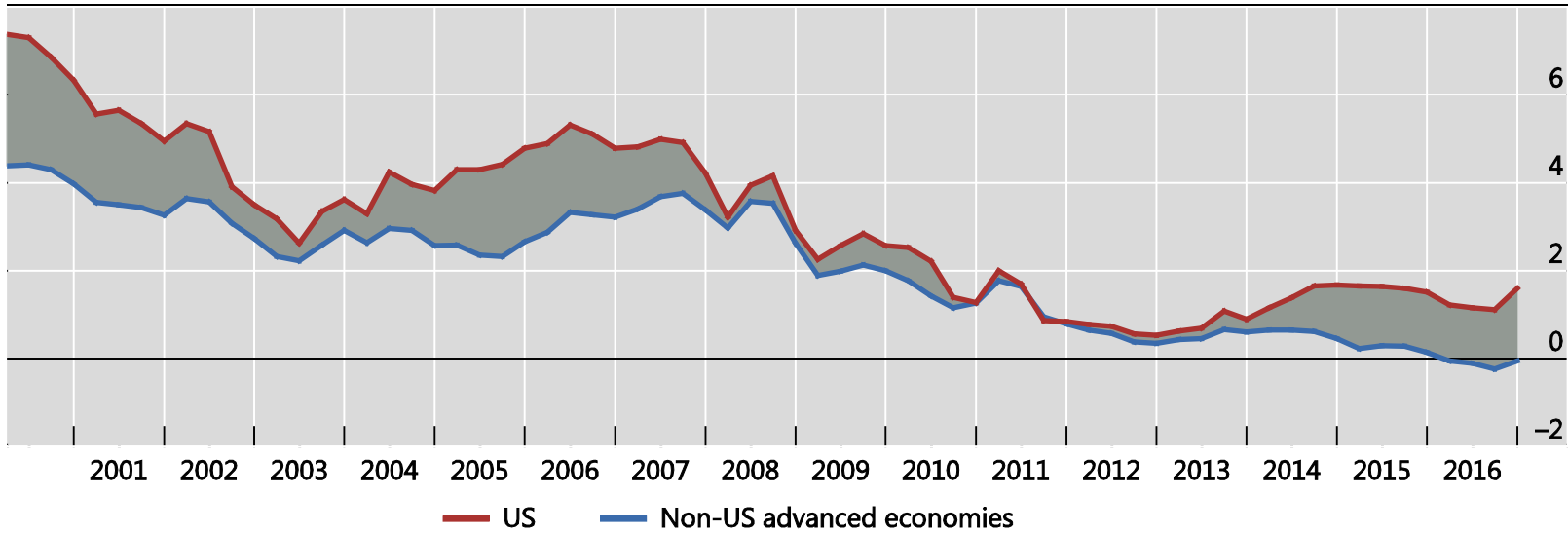

Non-US advanced economies equals the average of the 2-year futures for the United Kingdom, Switzerland, Japan and a group of "core" euro area countries (Austria, Belgium, Germany, Finland, France, the Netherlands and Spain).

Sources: Bloomberg; authors' calculations. 


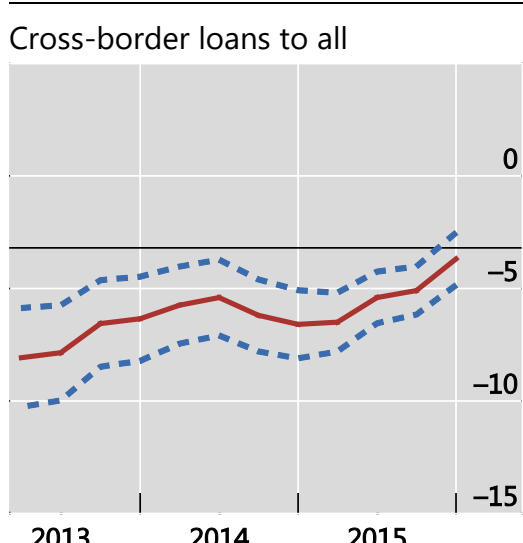

2013

IDS issued by all

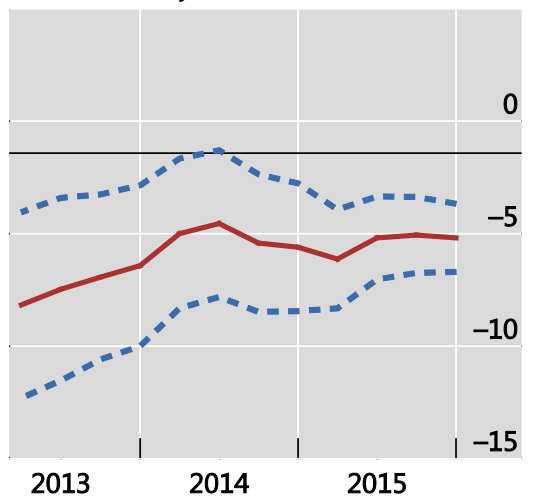

0

Cross-border loans to banks

0

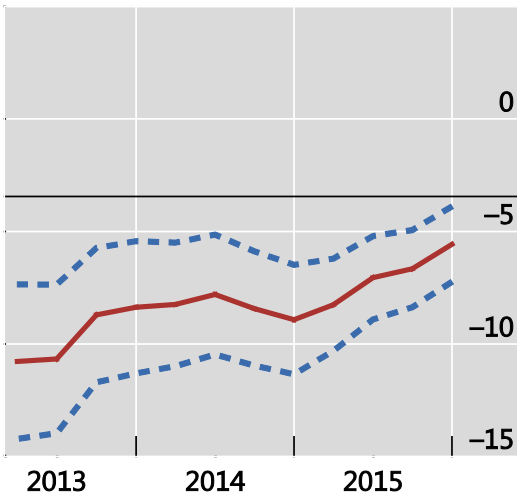

IDS issued by banks

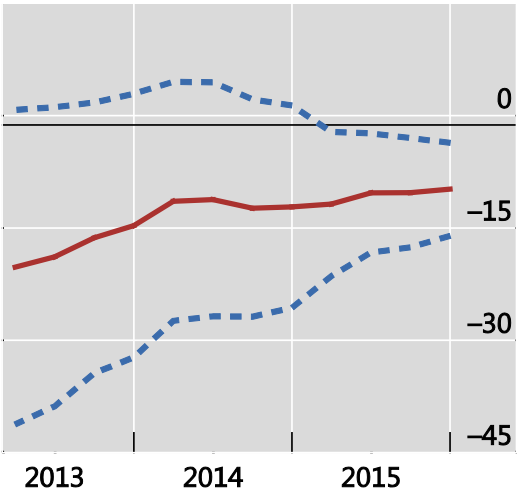

- estimate Confidence limit:
0

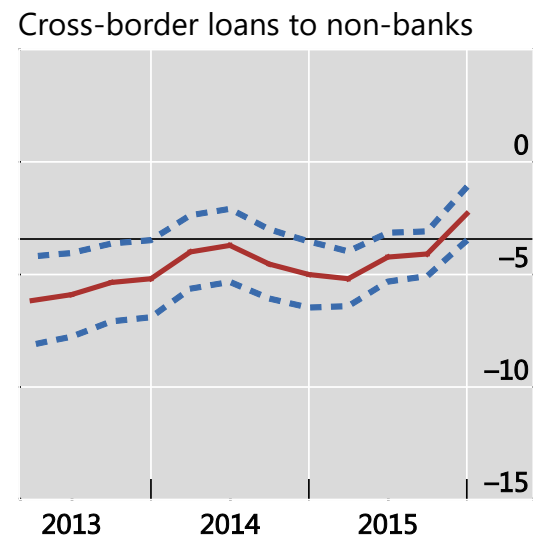

IDS issued by non-banks

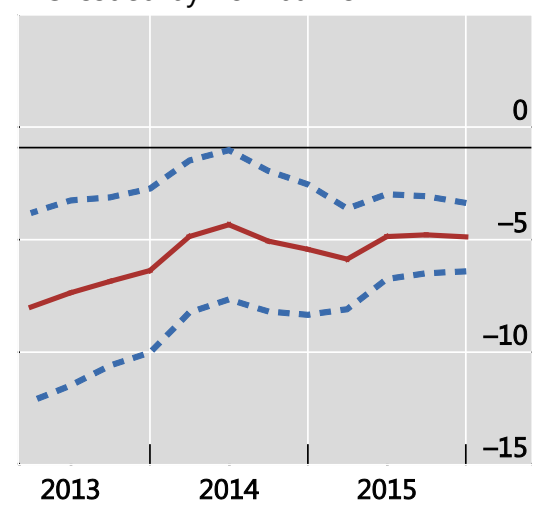
- - - Upper 90\%

The graph shows the evolution over time of sensitivities to the $\triangle F F R$. For each quarter $t$, the charts show the post-break coefficient (and its 90\% confidence interval) obtained by estimating the model with a sample from 2000:Q1 up to quarter $t$, with a break in 2009:Q1. The model includes the $\log (\mathrm{VIX}), \triangle$ Real GDP, $\triangle$ Sovereign Ratings, Chinn-Ito Index, $\triangle$ Real Global GDP, $\triangle F F R$ (i.e. $\Delta$ Effective federal funds rate for the period 2001:Q1 - 2008:Q4, $\triangle$ Wu-Xia Shadow rate for the period 2009:Q1 - 2015:Q4) as explanatory variables. The black line in each panel represents the pre-break estimate of the sensitivity to $\triangle F F R$.

Sources: authors' calculations. 


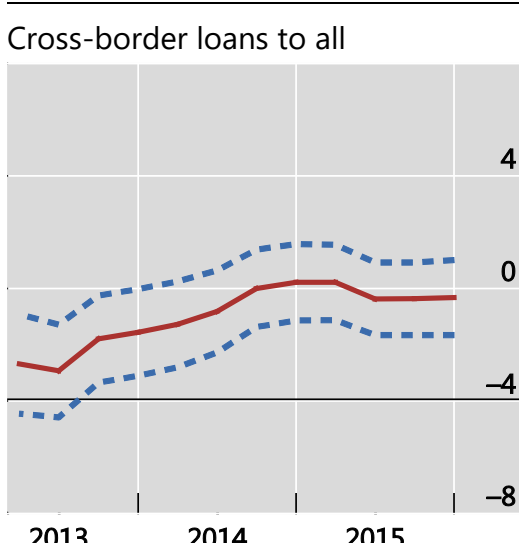

2013

IDS issued by all

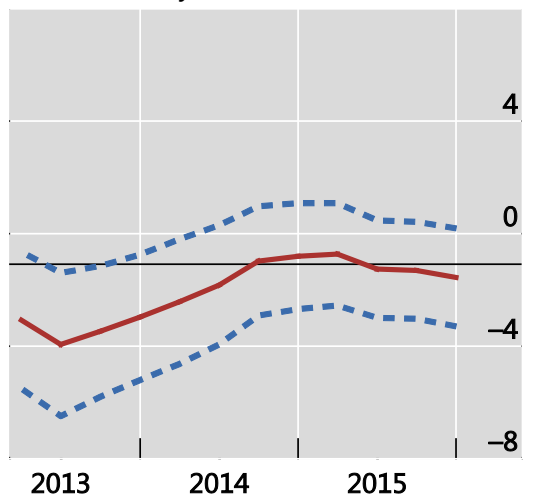

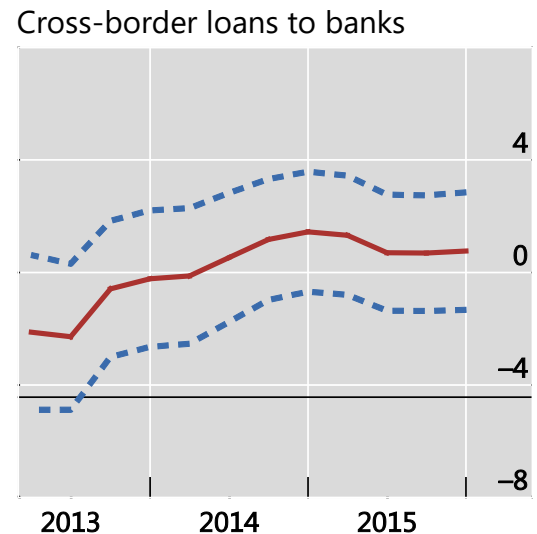

IDS issued by banks

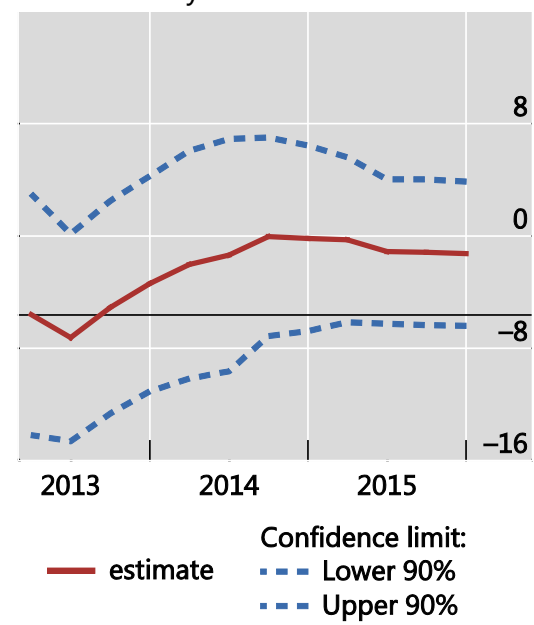

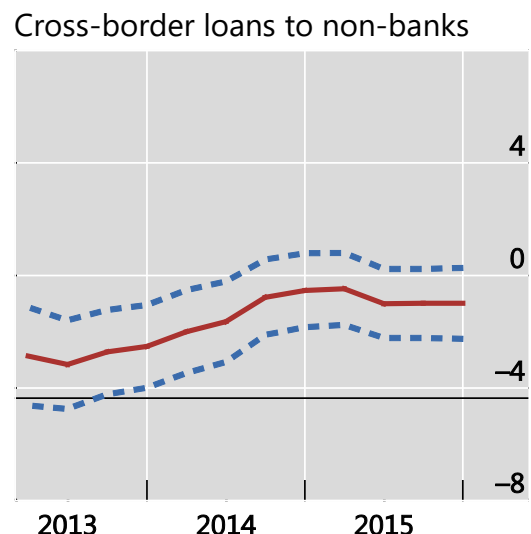

IDS issued by non-banks

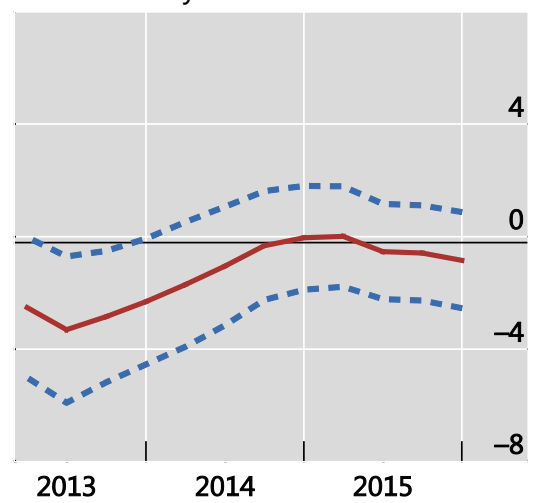

The graph shows the evolution over time of sensitivities to the $\log (\mathrm{VIX})$. For each quarter $\mathrm{t}$, the charts show the post-break coefficient (and its $90 \%$ confidence interval) obtained by estimating the model with a sample from 2000:Q1 up to quarter $t$, with a break in 2009:Q1. The model includes the $\log (\mathrm{VIX}), \Delta$ Real GDP, $\Delta$ Sovereign Ratings, Chinn-Ito Index, $\triangle$ Real Global GDP, $\triangle$ FFR (i.e. $\Delta$ Effective federal funds rate for the period 2001:Q1 - 2008:Q4, $\mathrm{W}$ W-Xia Shadow rate for the period 2009:Q1 - 2015:Q4) as explanatory variables. The black line in each panel represents the pre-break estimate of the sensitivity to the $\log (\mathrm{VIX})$.

Sources: authors' calculations. 

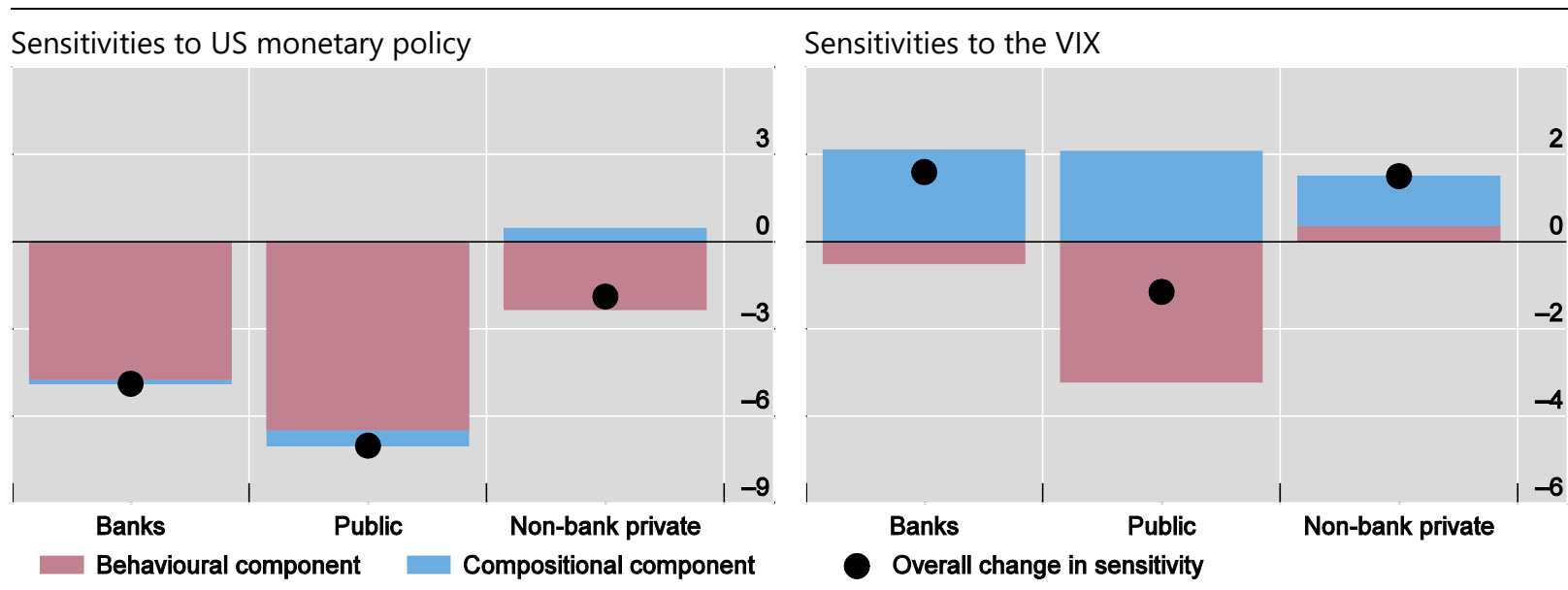

Sources: BIS consolidated banking statistics; authors' calculations.

Sensitivity of XB loans to all to change in FFR and MP divergence

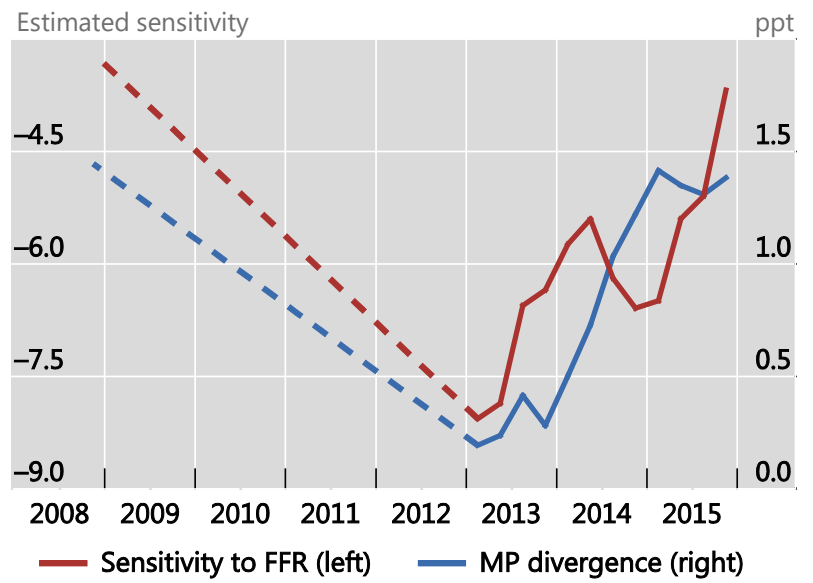

Sensitivity of XB loans to all to $\log (\mathrm{VIX})$ and average capitalization

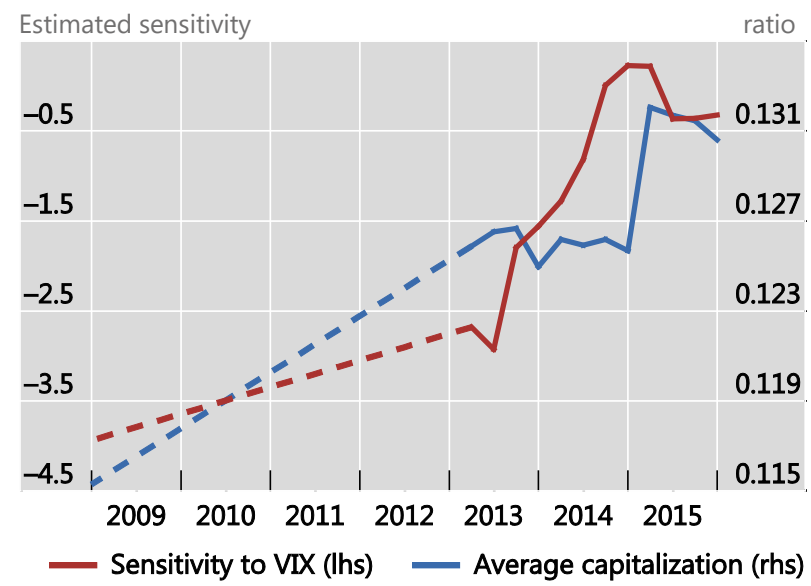

The solid red lines represent the (expanding window) sensitivities plotted in the top left hand panels of Graph 4 (for the FFR) and Graph 5 (for the VIX). The dashed red lines represent linearly interpolated values between the pre-GFC (Q1 2000 - Q4 2008) estimated sensitivities (solid black lines in the top left hand panels of Graphs 4 and 5, respectively) and the first point in time for which post-GFC estimates are available (i.e. Q1 2013). The solid blue lines represent the values of the respective drivers (MP divergence in the left-hand panel and a global weighted average of bank capitalisation levels) from Q1 2013 onwards. The dashed blue lines represent linearly interpolated values between the pre-GFC (Q1 2000 - Q4 2008) averages of the respective drivers (MP divergence in the left-hand panel and a global weighted average of bank capitalisation levels and their values in Q1 2013.

Source: authors' calculations. 


\section{Annex A: Country lists}

\section{Borrowing countries (64)}

Argentina (AR), Australia (AU), Austria (AT), Belgium (BE), Brazil (BR), Bulgaria (BG), Canada (CA), Chile (CL), China (CN), Colombia (CO), Croatia (HR), Czech Republic (CZ), Denmark (DK), Estonia (EE), Finland (FI), France (FR), Germany (DE), Greece (GR), Hong Kong SAR (HK), Hungary (HU), Iceland (IS), India (IN), Indonesia (ID), Ireland (IE), Israel (IL), Italy (IT), Japan (JP), Korea (KR), Kuwait (KW), Latvia (LV), Lebanon (LB), Lithuania (LT), Luxembourg (LU), Malaysia (MY), Malta (MT), Mexico (MX), Mongolia (MN), Netherlands (NL), New Zealand (NZ), Nigeria (NG), Norway (NO), Peru (PE), Philippines (PH), Poland (PL), Portugal (PT), Romania (RO), Russia (RU), Saudi Arabia (SA), Serbia (RS), Singapore (SG), Slovakia (SK), Slovenia (SI), South Africa (ZA), Spain (ES), Sweden (SE), Switzerland $(\mathrm{CH})$, Taiwan (TW), Thailand (TH), Turkey (TR), Ukraine (UA), United Kingdom (GB), United States (US), Uruguay (UY), Vietnam (VN).

\section{CBS lending bank nationalities (31)}

Australia (AU), Austria (AT), Belgium (BE), Brazil (BR), Canada (CA), Chile (CL), Denmark (DK), Finland $(\mathrm{FI})$, France (FR), Germany (DE), Greece (GR), Hong Kong SAR (HK), India (IN), Ireland (IE), Italy (IT), Japan (JP), Korea (KR), Luxembourg (LU), Mexico (MX), Netherlands (NL), Norway (NO), Panama (PA), Portugal (PT), Singapore (SG), Spain (ES), Sweden (SE), Switzerland (CH), Taiwan (TW), Turkey (TR), United Kingdom (GB), United States (US). 


\section{Annex B: Supplemental tables and graphs}

Table B1 - Descriptive statistics of the explanatory variables

\begin{tabular}{|c|c|c|c|c|c|}
\hline Variables & Obs. & Mean & Std. Dev. & Min & Max \\
\hline \multicolumn{6}{|l|}{ Global factors } \\
\hline$\Delta$ Fed fund rates (1) & 4,069 & -0.08 & 0.52 & -1.73 & 1.00 \\
\hline Log (VIX) & 4,069 & 2.97 & 0.34 & 2.40 & 4.07 \\
\hline$\Delta$ Global GDP & 4,069 & 3.66 & 1.67 & -2.49 & 5.75 \\
\hline$\Delta$ Other AE monetary policy (2) & 4,069 & -0.08 & 0.48 & -1.64 & 1.73 \\
\hline$\Delta 1$-year US Treasury rates & 4,069 & -0.09 & 0.40 & -1.51 & 0.60 \\
\hline$\Delta 2$-year US Treasury rates & 4,069 & -0.09 & 0.40 & -1.46 & 0.77 \\
\hline$\Delta 10$-year US Treasury rates & 4,069 & -0.07 & 0.34 & -0.83 & 0.72 \\
\hline \multicolumn{6}{|l|}{ Country-specific variables } \\
\hline$\Delta \mathrm{GDP}$ & 3,658 & 3.15 & 3.91 & -19.30 & 28.10 \\
\hline$\Delta$ Sovereign ratings (3) & 3,901 & 0.01 & 0.26 & -4.67 & 2.43 \\
\hline Chinn-Ito index (4) & 3,872 & 0.74 & 0.32 & 0.00 & 1.00 \\
\hline$\Delta$ Policy rates & 2,551 & -0.10 & 1.47 & -39.44 & 33.91 \\
\hline$\Delta$ Exchange rate vis à vis the US dollar & 3,879 & 0.002 & 0.04 & -0.17 & 0.42 \\
\hline \multicolumn{6}{|l|}{ Prudential tools (5) } \\
\hline LTV caps (6) & 1,149 & 0.47 & 1.73 & -3.00 & 8.00 \\
\hline Capital requirements (7) & 3,192 & 0.16 & 0.41 & 0.00 & 2.00 \\
\hline \multicolumn{6}{|l|}{ Lenders' balance sheet characteristics } \\
\hline Pre-break capital ratio (8) & 30 & 0.08 & 0.04 & 0.04 & 0.24 \\
\hline Pre-break average bank size (8) & 30 & 14.92 & 1.14 & 12.84 & 17.01 \\
\hline Pre-break deposits to total assets (8) & 30 & 0.75 & 0.10 & 0.53 & 0.94 \\
\hline Net interest income to total assets (9) & 4,069 & 0.63 & 0.50 & -3.81 & 2.96 \\
\hline Interest income to total income (9) & 4,069 & 0.66 & 0.03 & 0.52 & 0.77 \\
\hline Equity to total assets (9) & 4,069 & 0.12 & 0.02 & 0.07 & 0.19 \\
\hline \multicolumn{6}{|l|}{ Monetary policy divergence proxy } \\
\hline $\begin{array}{l}\text { Spread on 2-year futures on the policy } \\
\text { rate (10) }\end{array}$ & 4,069 & 1.05 & 0.76 & 0.01 & 3.00 \\
\hline \multicolumn{6}{|c|}{$\begin{array}{l}\text { Notes: The sample includes quarterly data for } 64 \text { recipient countries over the period 2000:Q1 - 2015:Q4, except for the } \\
\text { prudential tools for which the data end in 2014:Q4. (1) Effective federal funds rate for the period 2000:Q1 - 2008:Q4, Wu-Xia } \\
\text { Shadow rate for the period 2009:Q1 - 2015:Q4. (2) Simple average of the Krippner shadow rates for the Euro area, the UK } \\
\text { and Japan. (3) Long term foreign currency sovereign rating, average across } 3 \text { agencies (S\&P, Moody's and Fitch). (4) Measure } \\
\text { of financial openness developed in Chinn and Ito (2008). (5) A higher prudential index indicates a tightening. (6) Cumulative } \\
\text { caps on loan to value ratio. (7) Cumulative capital requirements. Each cumulative prudential index is obtained in each quarter } \\
\text { by adding the non-cumulative prudential index up to that quarter. (8) These aggregate balance sheet characteristics of the } \\
\text { banking sector pertain to the } 30 \text { lending countries in our sample. They refer to the end of the year 2008, right before the } \\
\text { structural break in our model. (9) This variable is borrower-specific and is computed as the weighted average for all countries } \\
\text { lending to a specific borrower. (10) Difference between 2-year futures contract on the US policy rate and the simple average of } \\
\text { similar futures contracts for other advanced economies (CH, EUR, JP, UK). }\end{array}$} \\
\hline
\end{tabular}


Table B2 - Formal tests of the significance in the differences between the estimated coefficients of US monetary policy and global risk for key sample periods

\begin{tabular}{|c|c|c|c|}
\hline & $\begin{array}{c}\text { Dependent variable: } \\
\Delta \text { Cross-border loans } \dagger\end{array}$ & $\begin{array}{c}\text { Dependent variable: } \\
\Delta \text { International debt securities } \ddagger\end{array}$ & $\begin{array}{c}\text { Dependent variable: } \\
\Delta \text { Total cross-border flows (loans } \\
\text { and debt securities) } \\
\end{array}$ \\
\hline \multicolumn{4}{|c|}{ Difference between post-break - up to 2013:Q1 - and pre-break coefficients } \\
\hline$\Delta F F(1)$ & $\begin{array}{c}-4.82 * * * \\
(1.42)\end{array}$ & $\begin{array}{c}-6.63 * * * \\
(2.71)\end{array}$ & $\begin{array}{c}-5.82 * * * \\
(1.06)\end{array}$ \\
\hline VIX (2) & $\begin{array}{c}1.56 \\
(1.41)\end{array}$ & $\begin{array}{l}-1.76 \\
(1.94)\end{array}$ & $\begin{array}{c}0.16 \\
(1.05)\end{array}$ \\
\hline
\end{tabular}

Difference between post-break - up to 2015:Q4 - and post-break - up to 2013:Q1 - coefficients

\begin{tabular}{lc|c|c}
$\Delta \mathrm{FF}(1)$ & $4.39 * * *$ & 2.98 & $3.59 * * *$ \\
& $(1.51)$ & $(2.67)$ & $(1.11)$ \\
$\mathrm{VIX}(2)$ & 2.36 & 1.52 & $1.96 * *$ \\
& $(1.34)$ & $(1.82)$ & $(1.03)$ \\
\hline
\end{tabular}

Difference between post-break - up to 2015:Q4 - and pre-break coefficients

\begin{tabular}{cc|c|c}
$\Delta \mathrm{FF}(1)$ & -0.43 & $-3.65^{* * *}$ & $-2.23^{* * *}$ \\
& $(0.86)$ & $(1.38)$ & $(0.59)$ \\
VIX (2) & $3.92 * * *$ & -0.24 & $2.12 * * *$ \\
& $(1.22)$ & $(1.65)$ & $(0.88)$ \\
\hline
\end{tabular}

Notes: The sample includes quarterly data for 64 recipient countries over the period 2000:Q1 - 2015:Q4. Robust standard errors in parentheses. ${ }^{* * *} \mathrm{p}<0.01,{ }^{* *} \mathrm{p}<0.05, * \mathrm{p}<0.1$. $\dagger$ to borrowers in country j. $¥$ issued by borrowers in country j. (1) Effective federal funds rate for the period 2000:Q1 - 2008:Q4, Wu-Xia Shadow rate for the period 2009:Q1 - 2015:Q4. (2) Log(VIX). The regressions include $\Delta$ Real GDP, $\Delta$ Sovereign Ratings, Chinn-Ito Index, $\Delta$ Real Global GDP and their interaction with a break dummy that takes value 1 after the break date (2009:Q1). The regressions also include a full set of country fixed effects. 
Table B3 - Locational baseline regressions (by borrowing country) with alternative measures of US monetary policy

\begin{tabular}{|c|c|c|c|c|c|c|}
\hline \multirow[b]{2}{*}{ Explanatory variables } & \multicolumn{3}{|c|}{$\begin{array}{c}\text { Dependent variable: } \\
\Delta \text { Cross-border loans }^{\dagger}\end{array}$} & \multicolumn{3}{|c|}{$\begin{array}{c}\text { Dependent variable: } \\
\Delta \text { International debt securities }\end{array}$} \\
\hline & All & to banks & to non-banks & All & by banks & by non-banks \\
\hline \multicolumn{7}{|c|}{ Krippner rates as a measure of US monetary policy } \\
\hline $\begin{array}{l}\Delta \text { Krippner }(1) \\
\text { Log(VIX) }\end{array}$ & $\begin{array}{c}-1.12 * * * \\
(0.27) \\
-3.87 * * * \\
(0.71) \\
\end{array}$ & $\begin{array}{c}-0.77 * * \\
(0.39) \\
-2.88 * * \\
(1.16) \\
\end{array}$ & $\begin{array}{c}-1.21 * * * \\
(0.29) \\
-4.29 * * * \\
(0.78) \\
\end{array}$ & $\begin{array}{c}-0.81 \\
(0.54) \\
-2.85^{* * *} \\
(0.99) \\
\end{array}$ & $\begin{array}{c}-1.72 * * \\
(0.84) \\
-7.47 * * * \\
(2.53) \\
\end{array}$ & $\begin{array}{c}-0.73 \\
(0.54) \\
-2.09 * * \\
(0.97) \\
\end{array}$ \\
\hline \multicolumn{7}{|c|}{ Bauer-Rudebusch rates as a measure of US monetary policy } \\
\hline $\begin{array}{l}\Delta \text { Bauer-Rudebusch (2) } \\
\text { Log(VIX) }\end{array}$ & $\begin{array}{c}-1.78 * * * \\
(0.44) \\
-3.33 * * * \\
(0.63) \\
\end{array}$ & $\begin{array}{c}-1.84 * * * \\
(0.64) \\
-2.99 * * * \\
(1.04) \\
\end{array}$ & $\begin{array}{c}-1.99 * * * \\
(0.49) \\
-3.77 * * * \\
(0.68) \\
\end{array}$ & $\begin{array}{c}-2.04 * * \\
(1.00) \\
-3.04 * * * \\
(0.78) \\
\end{array}$ & $\begin{array}{c}-0.24 \\
(1.54) \\
-4.72 * * \\
(2.14) \\
\end{array}$ & $\begin{array}{c}-1.78 * * * \\
(0.44) \\
-3.34 * * * \\
(0.63) \\
\end{array}$ \\
\hline \multicolumn{7}{|c|}{ 2-year US treasury bond rates as a measure of US monetary policy } \\
\hline $\begin{array}{l}\Delta \text { 2-year US rates (3) } \\
\text { Log(VIX) }\end{array}$ & $\begin{array}{c}-2.156 * * * \\
(0.558) \\
-3.008 * * * \\
(0.702) \\
\end{array}$ & $\begin{array}{l}-1.436 * \\
(0.848) \\
-1.828 \\
(1.137) \\
\end{array}$ & $\begin{array}{c}-2.848 * * * \\
(0.607) \\
-3.932 * * * \\
(0.748) \\
\end{array}$ & $\begin{array}{l}-0.585 \\
(1.370) \\
-1.613^{*} \\
(0.966)\end{array}$ & $\begin{array}{l}-0.280 \\
(1.973) \\
-3.916^{*} \\
(2.298) \\
\end{array}$ & $\begin{array}{l}-0.256 \\
(1.514) \\
-0.799 \\
(1.065) \\
\end{array}$ \\
\hline $\begin{array}{l}\text { Notes: The sample include } \\
\text { of country fixed effects. R } \\
\text { borrowers in country j. (1) } \\
\text { based on Bauer and Rude } \\
\text { Ratings, Chinn-Ito Index, } \\
\text { The regressions also includ }\end{array}$ & $\begin{array}{l}\text { erly data for } 6 \\
\text { tandard error } \\
\text { late of the Fe } \\
\text { (2016). (3) I } \\
\text { Slobal GDP a } \\
\text { I set of countr }\end{array}$ & $\begin{array}{l}\text { pient countri } \\
\text { arentheses. * } \\
\text { shadow rat } \\
\text { rates on 2- } \\
\text { ir interactior } \\
\text { d effects. }\end{array}$ & $\begin{array}{l}\text { er the period } 20 \\
0.01, * * \mathrm{p}<0.0 \\
\text { ed on Krippne } \\
\text { US Treasuries. } \\
\text { a break dumm }\end{array}$ & $\begin{array}{l}\mathrm{Q} 1-2015: \mathrm{C} \\
\mathrm{p}<0.1 .^{\dagger} \text { to } \\
14) .(2) \mathrm{M} \\
\text { regressior } \\
\text { at takes val }\end{array}$ & $\begin{array}{l}\text { he regressio } \\
\text { owers in co } \\
\text { e of the Fe } \\
\text { lude } \Delta \text { Real } \\
\text { after the bre }\end{array}$ & $\begin{array}{l}\text { include a full set } \\
\text { try j. }{ }^{\ddagger} \text { issued by } \\
\text { und shadow rate } \\
\text { DP, } \Delta \text { Sovereign } \\
\text { date (2009:Q1). }\end{array}$ \\
\hline
\end{tabular}


Table B4 - Locational baseline regressions (by borrowing country) with additional controls

\begin{tabular}{|c|c|c|c|c|c|c|}
\hline \multirow[b]{2}{*}{ Explanatory variables } & \multicolumn{3}{|c|}{$\begin{array}{c}\text { Dependent variable: } \\
\Delta \text { Cross-border loans }^{\dagger}\end{array}$} & \multicolumn{3}{|c|}{$\begin{array}{c}\text { Dependent variable: } \\
\Delta \text { International debt securities } \neq\end{array}$} \\
\hline & All & to banks & $\begin{array}{c}\text { to non- } \\
\text { banks }\end{array}$ & All & by banks & $\begin{array}{c}\text { by non- } \\
\text { banks }\end{array}$ \\
\hline$\Delta$ Fed funds rate (1) & $\begin{array}{c}-1.550 * * * \\
(0.484)\end{array}$ & $\begin{array}{c}-2.230 * * * \\
(0.729)\end{array}$ & $\begin{array}{c}-1.337 * * \\
(0.543)\end{array}$ & $\begin{array}{c}-0.807 * \\
(0.474)\end{array}$ & $\begin{array}{c}-1.831 \\
(1.378)\end{array}$ & $\begin{array}{c}-0.606 \\
(0.481)\end{array}$ \\
\hline Log(VIX) & $\begin{array}{l}-1.364 \\
(0.845)\end{array}$ & $\begin{array}{c}-0.578 \\
(1.336)\end{array}$ & $\begin{array}{c}-2.696 * * * \\
(0.985)\end{array}$ & $\begin{array}{c}-1.875 * * \\
(0.748)\end{array}$ & $\begin{array}{l}-3.483 \\
(3.734)\end{array}$ & $\begin{array}{l}-0.493 \\
(0.970)\end{array}$ \\
\hline$\Delta$ Real GDP & $\begin{array}{c}0.639 * * * \\
(0.0931)\end{array}$ & $\begin{array}{c}0.810^{* * *} \\
(0.141)\end{array}$ & $\begin{array}{c}0.534^{* * *} \\
(0.102)\end{array}$ & $\begin{array}{c}0.0902 \\
(0.0916)\end{array}$ & $\begin{array}{l}0.0474 \\
(0.372)\end{array}$ & $\begin{array}{c}-0.00160 \\
(0.102)\end{array}$ \\
\hline$\Delta$ Sovereign rating (2) & $\begin{array}{l}0.337^{*} \\
(0.197)\end{array}$ & $\begin{array}{c}0.757 * * * \\
(0.270)\end{array}$ & $\begin{array}{c}0.204 \\
(0.197)\end{array}$ & $\begin{array}{c}-0.0636 \\
(0.178)\end{array}$ & $\begin{array}{c}-0.544 \\
(0.769)\end{array}$ & $\begin{array}{c}0.149 \\
(0.226)\end{array}$ \\
\hline Chinn-Ito index (3) & $\begin{array}{l}2.836 * \\
(1.553)\end{array}$ & $\begin{array}{l}3.371 * \\
(2.031)\end{array}$ & $\begin{array}{c}0.311 \\
(1.281)\end{array}$ & $\begin{array}{l}-0.779 \\
(1.086)\end{array}$ & $\begin{array}{l}-1.059 \\
(2.382)\end{array}$ & $\begin{array}{l}-0.913 \\
(1.256)\end{array}$ \\
\hline$\Delta$ Real global GDP & $\begin{array}{l}-1.526 \\
(2.380)\end{array}$ & $\begin{array}{l}-2.730 \\
(3.431)\end{array}$ & $\begin{array}{c}-0.678 \\
(2.518)\end{array}$ & $\begin{array}{c}6.706^{* * *} \\
(1.691)\end{array}$ & $\begin{array}{c}8.553 \\
(6.323)\end{array}$ & $\begin{array}{c}3.605^{* *} \\
(1.792)\end{array}$ \\
\hline$\Delta$ Local policy rates & $\begin{array}{c}0.320 \\
(0.256)\end{array}$ & $\begin{array}{c}-0.152 \\
(0.458)\end{array}$ & $\begin{array}{c}0.551 * * \\
(0.251)\end{array}$ & $\begin{array}{r}-0.0635 \\
(0.229)\end{array}$ & $\begin{array}{c}2.031 \\
(1.249)\end{array}$ & $\begin{array}{l}-0.275 \\
(0.288)\end{array}$ \\
\hline$\Delta 10$-year US rates & $\begin{array}{c}0.669 \\
(0.692)\end{array}$ & $\begin{array}{c}1.388 \\
(1.011)\end{array}$ & $\begin{array}{l}-0.657 \\
(0.783)\end{array}$ & $\begin{array}{c}0.969 \\
(0.600)\end{array}$ & $\begin{array}{c}1.789 \\
(4.506)\end{array}$ & $\begin{array}{l}1.728^{*} \\
(1.049)\end{array}$ \\
\hline$\Delta \log ($ exchange rates) $(4)$ & $\begin{array}{c}-42.92 * * * \\
(4.193)\end{array}$ & $\begin{array}{c}-53.85 * * * \\
(6.356)\end{array}$ & $\begin{array}{c}-32.26 * * * \\
(4.563)\end{array}$ & $\begin{array}{c}-34.39 * * * \\
(3.504)\end{array}$ & $\begin{array}{c}-93.51 * * * \\
(30.09)\end{array}$ & $\begin{array}{c}-32.72 * * * \\
(3.725)\end{array}$ \\
\hline$\Delta$ other AE MP (5) & $\begin{array}{c}0.56 \\
(0.97) \\
\end{array}$ & $\begin{array}{c}2.58 * * \\
(1.24) \\
\end{array}$ & $\begin{array}{c}1.43 \\
(1.23) \\
\end{array}$ & $\begin{array}{c}0.04 \\
(0.27) \\
\end{array}$ & $\begin{array}{l}1.82 * * \\
(1.14)\end{array}$ & $\begin{array}{c}1.31 \\
(1.35)\end{array}$ \\
\hline Lagged dependent var. & yes & yes & yes & yes & yes & yes \\
\hline Observations & 2,252 & 2,252 & 2,252 & 2,252 & 2,021 & 2,252 \\
\hline R-squared & 0.151 & 0.111 & 0.086 & 0.091 & 0.041 & 0.063 \\
\hline
\end{tabular}

Notes: The sample includes quarterly data for 64 recipient countries over the period 2000:Q1 - 2015:Q4. The regressions include a full set of country fixed effects. Robust standard errors in parentheses. ${ }^{* * *} \mathrm{p}<0.01,{ }^{* *} \mathrm{p}<0.05,{ }^{*} \mathrm{p}<0.1{ }^{\dagger}{ }^{\dagger}$ to borrowers in country j. ${ }^{*}$ issued by borrowers in country j. (1) Interest rates on 1-year US Treasuries. (2) Long term foreign currency sovereign rating, average across 3 agencies (S\&P, Moody's and Fitch). (3) Measure of financial openness developed in Chinn and Ito (2008). (4) Exchange rates vis à vis the US dollar. (5) Simple average of the Krippner shadow rates for the Euro area, the UK and Japan. 
Table B5 - Locational baseline regressions (by borrowing country) with additional controls and structural breaks

\begin{tabular}{|c|c|c|c|}
\hline & $\begin{array}{c}\text { Dependent variable: } \\
\Delta \text { Cross-border loans } \dagger \\
\end{array}$ & $\begin{array}{c}\text { Dependent variable: } \\
\Delta \text { International debt securities } \ddagger\end{array}$ & $\Delta$ Total cross-border flows \\
\hline \multicolumn{4}{|l|}{ Pre } \\
\hline$\Delta \mathrm{FF}(1)$ & $\begin{array}{c}-3.40 * * * \\
(0.70)\end{array}$ & $\begin{array}{l}-0.81 \\
(0.68)\end{array}$ & $\begin{array}{c}-2.22 * * * \\
(0.48)\end{array}$ \\
\hline VIX (2) & $\begin{array}{c}-4.04 * * * \\
(1.44)\end{array}$ & $\begin{array}{l}-1.99 \\
(1.30)\end{array}$ & $\begin{array}{c}-3.13^{* * *} \\
(1.01)\end{array}$ \\
\hline \multicolumn{4}{|c|}{ Post - up to 2013:Q1 } \\
\hline$\Delta \mathrm{FF}(1)$ & $\begin{array}{c}-4.30 * * \\
(2.07)\end{array}$ & $\begin{array}{l}-1.42 \\
(1.56)\end{array}$ & $\begin{array}{c}-2.88^{* *} \\
(1.29)\end{array}$ \\
\hline VIX (2) & $\begin{array}{c}0.06 \\
(1.64) \\
\end{array}$ & $\begin{array}{c}-4.63 * * \\
(1.90) \\
\end{array}$ & $\begin{array}{l}-0.85 \\
(1.12) \\
\end{array}$ \\
\hline \multicolumn{4}{|c|}{ Post - up to 2015:Q4 } \\
\hline$\Delta \mathrm{FF}(1)$ & $\begin{array}{l}-1.13 \\
(0.94)\end{array}$ & $\begin{array}{c}-1.86 * * * \\
(0.65)\end{array}$ & $\begin{array}{c}-1.28 * * \\
(0.59)\end{array}$ \\
\hline VIX (2) & $\begin{array}{c}1.34 \\
(1.07) \\
\end{array}$ & $\begin{array}{l}-2.19 * * \\
(1.02) \\
\end{array}$ & $\begin{array}{c}0.30 \\
(0.71) \\
\end{array}$ \\
\hline \multicolumn{4}{|c|}{$\begin{array}{l}\text { Notes: Quarterly data, } 64 \text { recipient countries, } 2000: \mathrm{Q} 1-2015: \mathrm{Q} 4 \text {. Robust standard errors in parentheses. } * * * \mathrm{p}<0.01, * * \\
\mathrm{p}<0.05, * \mathrm{p}<0.1 \text {. } \dagger \text { to borrowers in country j. } ¥ \text { issued by borrowers in country j. (1) Effective federal funds rate for the } \\
\text { period 2000:Q1 - 2008:Q4, Wu-Xia Shadow rate for the period 2009:Q1 }-2015: \mathrm{Q} 4 \text {. ( } 2 \text { ) Log(VIX). The regressions } \\
\text { include country fixed effects, lagged dependent variable, } \Delta \text { Real GDP, } \Delta \text { Sovereign Ratings, Chinn-Ito Index, } \Delta \text { Real Globa } \\
\text { GDP, } \Delta \text { Local policy rates, } \Delta 10 \text {-year US rates, } \Delta \text { Log(exchange rates), } \Delta \text { other advanced economy monetary policy } \\
\text { computed as the simple average of the Krippner shadow rates for the Euro Area, Japan and the UK and interaction with a } \\
\text { dummy that equals } 1 \text { after 2009:Q1. }\end{array}$} \\
\hline
\end{tabular}

Table B6 - Baseline model with alternative measures of portfolio debt flows

\begin{tabular}{|c|c|c|c|}
\hline \multirow[b]{2}{*}{ Explanatory variables } & \multicolumn{3}{|c|}{$\begin{array}{c}\text { Dependent variable: } \\
\Delta \text { Portfolio debt flows }^{\dagger}\end{array}$} \\
\hline & All & by banks & by non-banks \\
\hline$\Delta$ Fed funds rate (1) & $\begin{array}{c}-1.69 * * * \\
(0.26)\end{array}$ & $\begin{array}{c}-1.81^{* * *} \\
(0.50)\end{array}$ & $\begin{array}{c}-1.85 * * * \\
(0.27)\end{array}$ \\
\hline $\log (V I X)$ & $\begin{array}{c}-3.08 * * * \\
(0.44)\end{array}$ & $\begin{array}{c}-4.96 * * * \\
(0.83)\end{array}$ & $\begin{array}{c}-2.56 * * * \\
(0.46)\end{array}$ \\
\hline$\Delta$ Real GDP & $\begin{array}{c}0.04 \\
(0.04)\end{array}$ & $\begin{array}{c}0.10 \\
(0.08)\end{array}$ & $\begin{array}{c}0.03 \\
(0.05)\end{array}$ \\
\hline$\Delta$ Sovereign rating (2) & $\begin{array}{c}1.10^{* * * *} \\
(0.40)\end{array}$ & $\begin{array}{c}2.91^{* * * *} \\
(0.82)\end{array}$ & $\begin{array}{c}0.48 \\
(0.56)\end{array}$ \\
\hline Chinn-Ito index (3) & $\begin{array}{l}3.17 * * \\
(1.31)\end{array}$ & $\begin{array}{l}4.81^{*} \\
(2.88)\end{array}$ & $\begin{array}{l}-0.31 \\
(1.31)\end{array}$ \\
\hline$\Delta$ Real global GDP & $\begin{array}{l}0.058 \\
(0.09)\end{array}$ & $\begin{array}{c}0.26 \\
(0.18)\end{array}$ & $\begin{array}{c}-0.01 \\
(0.102)\end{array}$ \\
\hline $\begin{array}{l}\text { Observations } \\
\text { R-squared }\end{array}$ & $\begin{array}{c}2,592 \\
0.07\end{array}$ & $\begin{array}{c}2,447 \\
0.07\end{array}$ & $\begin{array}{c}2,592 \\
0.05\end{array}$ \\
\hline $\begin{array}{l}\text { Notes: The sample incl } \\
\text { include a full set of coun } \\
\text { of outstanding stocks of } \\
\text { the period 2000:Q1 - } 200 \\
3 \text { agencies. (3) Measure }\end{array}$ & $\begin{array}{l}\text { ata for } 64 \\
\text { Robust sta } \\
\text { orrowers in } \\
\text { hadow rate } \\
\text { ness develo }\end{array}$ & $\begin{array}{l}\text { ver the per } \\
\text { theses. } * * * \\
d \text { at the } 10 \% \\
21-2015: Q \\
(2008) \text {. }\end{array}$ & $\begin{array}{l}\text { 5:Q4. The regressions } \\
* \mathrm{p}<0.1 .^{\dagger} \text { growth rate } \\
\text { e federal funds rate for } \\
\text { urrency, average across }\end{array}$ \\
\hline
\end{tabular}

